\section{To: (Receiving Organization) \\ Distribution}

5. Proj./Prog./Dept./Div.:

Faster/WESF project

\section{Originator Remarks:}

This FEMP has been updated to a stand alone version for WESF from WHC-EP-0467-1 "Facility Effluent Monitoring Plan for B Plant/WESF"
11. Receiver Remarks:

3. From: (Originating Organization)
$16 \mathrm{E} 00$
$\begin{aligned} & \text { 6. Design Authority/Design Agent/Cog. Engr: } \\ & \text { N/A }\end{aligned}$

6. Design Authority/Design Agent/Cog. Engr.

\author{
4. Related EDT No: \\ $\mathrm{N} / \mathrm{A}$ \\ 7. Purchase Order No: \\ $\mathrm{N} / \mathrm{A}$ \\ 9. Equip./Component No.: \\ $\mathrm{N} / \mathrm{A}$
}

10. System/Bldg./Facility:

WESE

12. Major Assm. Dwg. No.:

$\mathrm{N} / \mathrm{A}$

13. PermitPermit Application No:

$\mathrm{N} / \mathrm{A}$

14. Required Response Date:

$3 / 18 / 99$

\begin{tabular}{|c|c|c|c|c|c|c|c|c|}
\hline 15. & \multicolumn{4}{|c|}{ DATA TRANSMITTED } & (F) & (G) & (H) & (l) \\
\hline $\begin{array}{l}\text { (A) } \\
\text { Item } \\
\text { No. }\end{array}$ & (B) Document/Drawing No. & $\begin{array}{l}\text { (C) Sheet } \\
\text { No. }\end{array}$ & (D) Rev. & (E) Title or Description of Data Transmitted & $\begin{array}{l}\text { Approval } \\
\text { Desig- } \\
\text { nator }\end{array}$ & $\begin{array}{c}\text { Reason } \\
\text { for Trans- } \\
\text { mittal }\end{array}$ & $\begin{array}{c}\text { Origi- } \\
\text { nator } \\
\text { Dispo- } \\
\text { stion }\end{array}$ & $\begin{array}{c}\text { Receiv- } \\
\text { er } \\
\text { Dispo- } \\
\text { sition }\end{array}$ \\
\hline & HNE -4200 & $\mathrm{~N} / \mathrm{A}$ & 0 & EEMP for WESF & $\mathrm{E}$ & 1 & & \\
\hline
\end{tabular}

\begin{tabular}{|l|l|l|l|}
\hline $\mathrm{HNE}-4200$ & $\mathrm{~N} / \mathrm{A}$ & 0 \\
\hline & & & \\
\hline & & & \\
\hline & & & \\
\hline & & & \\
\hline
\end{tabular}

16.

KEY

\begin{tabular}{|c|c|c|c|c|}
\hline Approval Designator $(F)$ & \multicolumn{2}{|r|}{ Reason for Transmittal (G) } & \multicolumn{2}{|c|}{ Disposition (H) \& (I) } \\
\hline  & $\begin{array}{l}\text { 1. Approval } \\
\text { 2. Release } \\
\text { 3. Information }\end{array}$ & $\begin{array}{l}\text { 4. Review } \\
\text { 5. Post-Review } \\
\text { 6. Dist. (Receipt Acknow. Required) }\end{array}$ & $\begin{array}{l}\text { 1. Approved } \\
\text { 2. Approved w/comment } \\
\text { 3. Disapproved w/comment }\end{array}$ & $\begin{array}{l}\text { 4. Reviewed no/comment } \\
\text { 5. Reviewed w/comment } \\
6 \text {. Receipt acknowledged }\end{array}$ \\
\hline
\end{tabular}
17

(See Approval Designator for required signatures)

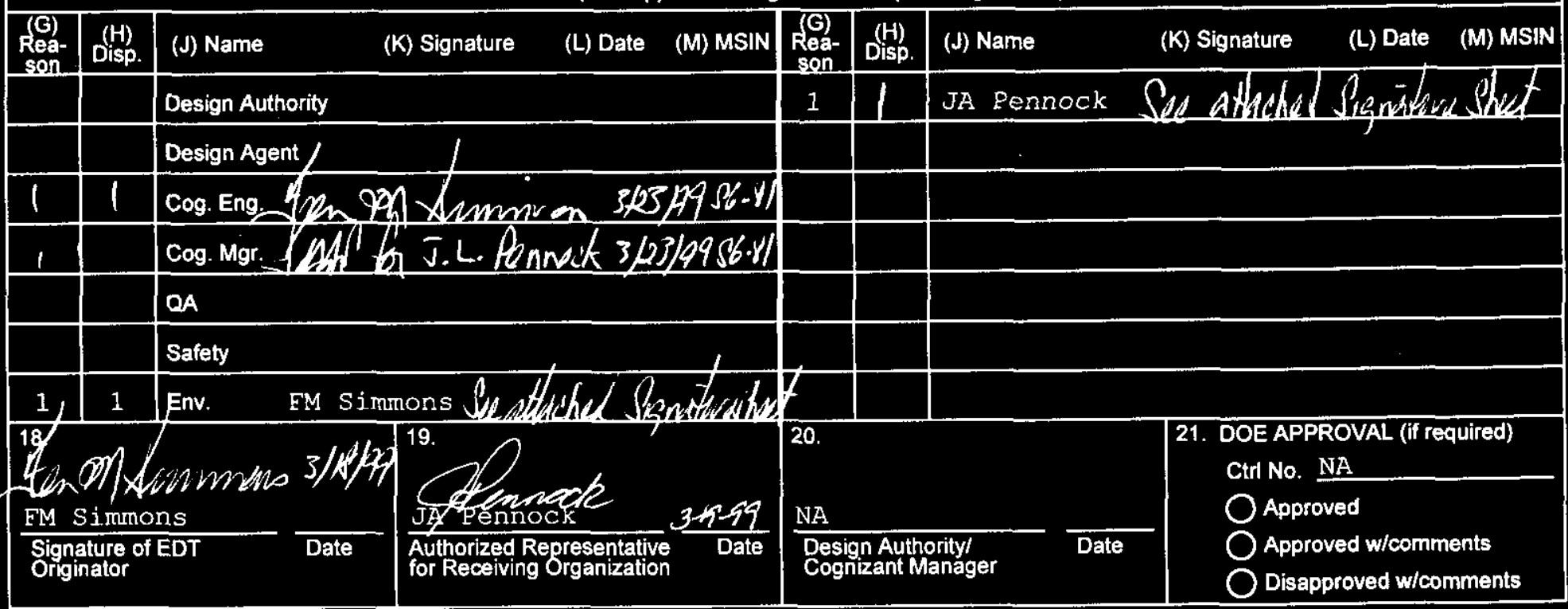




\title{
FACILITY EFFLUENT MONITORING PLAN FOR WESF
}

\author{
F. M. Simmons \\ B\&W Hanford Company \\ Richland, WA 99352 \\ U.S. Department of Energy Contract DE-AC06-96RL13200 \\ EDT/ECN: 624889 \\ $3 / 23 / 99$ \\ Org Code: 16E00 \\ B\&R Code: EW02J1120 \\ UC: 630 \\ $\begin{array}{lll}\text { Charge Code: } 101277 & \\ \text { Total Pages: } 72>7 / 25 / 99\end{array}$
}

Key Words: FEMP, 296-B-10 stack, WCW, WLE, Cooling Water, WESF

\begin{abstract}
The FEMP for the Waste Encapsulation and Storage Facility (WESF) provides sufficient iformation on the WESF efflluent characteristics and the effleuent monitoring systems so that a compliance assessment against applicable requirements may be performed. Radioactive and hazardous material source terms are related to specific effluent streams that are in turn, related to dishcarge points and, finally are compared to the effluent monitoring system capability.
\end{abstract}

TRADEMARK DISCLAIMER. Reference herein to any specific commercial product, process, or service by trade name, trademark, manufacturer, or otherwise, does not necessarily constitute or imply its endorsement, recommendation, or favoring by the United States Government or any agency thereof or its contractors or subcontractors.

Printed in the United States of America. To obtain copies of this document, contact: Document Control Services, P.O. Box 950, Mailstop H6-08, Richland WA 99352, Phone (509) 372-2420; Fax (509) 376-4989.
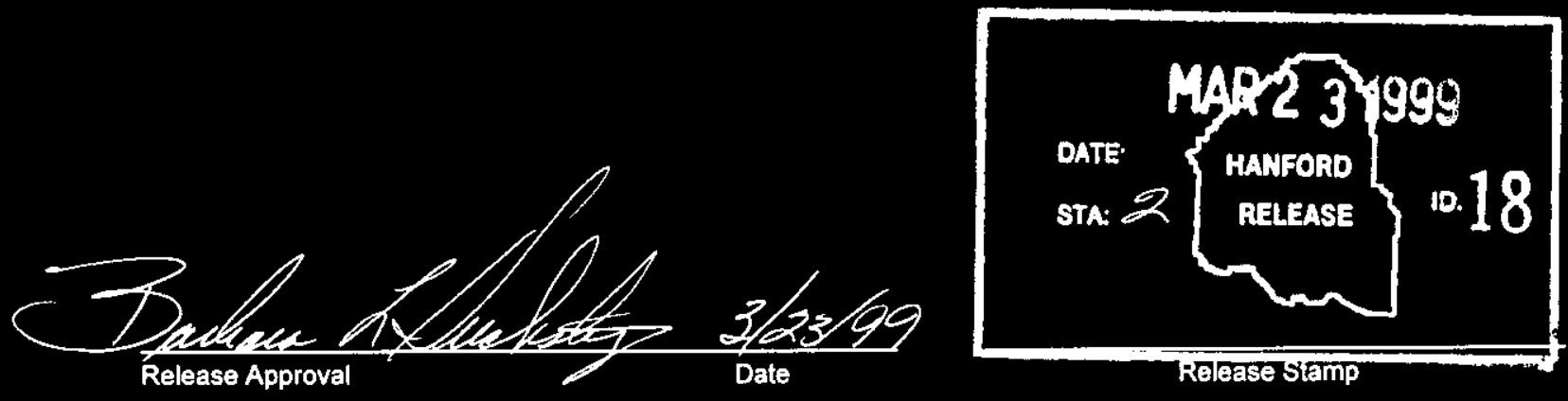

\section{Approved For Public Release}




\section{DISTRIBUTION}

\section{Number of Copies}

6

\section{U.S. Department of Energy, Richland Operations}

D. T. Evans

J. B. Hall

L. E. Rogers

H. M. Rodriguez

D. C. Ward

Public Reading Room

3 Pacific Northwest Laboratory

G. A. Simiele

P7-79

R. K. Woodruff

K6-13

Hanford Technical Library

P8-55

19 PHMC

J. A. Bates

W. E. Davis

L. P. Diediker

T. P. Frazier

D. W. Fritz

E. M. Greager

J. L. Pennock

J. K. Perry

D. G. Ranade

G. W. Reddick

E. D. Robbins

P. T. Saueressig

F. M. Simmons

W. R. Thackaberry

H6-23

H6-20

H6-36

H6-36

H6-22

H6-30

S6-81

H6-23

B2-16

ᄂ.5-65

S6-51

S6-81

S6-81

H6-32

W. W. Wingfield

S6-81

SWDPC-1

T3-05

Central Files

A3-88

OSTI (2) 
HNF-4200, Rev. 0

\section{APPROVAL PAGE}

Facility Effiluent Monitoring Plan for the Waste Encapsulation and Storage Facility Prepared By: $\frac{\text { F.M. Simmons - fen }}{\text { Environmental Compliance dficer }}$

Approved By: J.L.Pennock, Manager Lencecece Waste Encapsulation and Storage Facility
Date $3-18-99$

Date $3-19-99$ 
HNF-4200, Rev. 0

This page intentionally left blank. 


\title{
FACILITY EFFLUENT MONITORING PLAN FOR WASTE ENCAPSULATION AND STORAGE FACILITY
}

\begin{abstract}
A facility effluent monitoring plan is required by the U.S. Department of Energy in DOE Order 5400.11 for any operations that involve hazardous materials and radioactive substances that could impact employee or public safety or the environment. This document is prepared using the specific guidelines identified in "A Guide for Preparing Hanford Site Facility Effluent Monitoring Plans," WHC-EP-0438-12. This facility effluent monitoring plan assesses effluent monitoring systems and evaluates whether they are adequate to ensure the public health and safety as specified in applicable federal, state, and local requirements.
\end{abstract}

This facility effluent monitoring plan shall ensure long-range integrity of the effluent monitoring systems by requiring an update whenever a new process or operation introduces new hazardous materials or significant radioactive materials. This document must be reviewed annually even if no operational changes and it must be updated every three years.

1 General Environmental Protection Program, DOE Order 5400.1, U.S. Department of Energy, Washington, D.C., 1988.

2 A Guide for Preparing Hanford Site Facility Effluent Monitoring Plans, WHC-EP-0438-1, Westinghouse Hanford Company, Richland, Washington, 1992. 
HNF-4200, Rev. 0

This facility effluent monitoring plan has been revised to include procedure changes (revisions), and comparisons with the improved U.S. Environmental Protection Agency "National Emission Standards for Hazardous Air Pollutants"3 point-by-point evaluation.

3 National Emissions Standards for Hazardous Air Pollutants, Title 40, Code of Federal Regulations, Part 61, U.S. Environmental Protection Agency, Washington, D.C. 


\section{EXECUTIVE SUMMARY}

The U.S. Department of Energy (DOE) Organization Act of 1977 (DOE 1977)4 and the Atomic Energy Act of 1954 (AEA 1954), 5 as amended, provide for the protection of the health and safety of the public and environment. Recently, DOE issued new requirements for complying with DOE and other Federal agency environmental regulations. The DOE Order 5400.1 (DOE 1991c) requires a written environmental monitoring plan for each site, facility, or process that uses, generates, releases, or manages signiiicant contaminants of radioactive and/or hazardous materials.

The two major components of an environmental monitoring plan consist of a facility effluent monitoring plan (FEMP) and an environmental surveillance plan. As stated in a document issued by the U.S. Department of Energy, Richland Operations Office (DOE 1989), the Fluor Daniel Hanford Company has the responsibility for the preparation of the FEMPs at the Hanford Site.

The FEMP for the Waste Encapsulation and Storage Facility (WESF) provides sufficient information on the WESF effluent characteristics and the effluent monitoring systems so that a compliance assessment against applicable requirements may be performed. Radioactive and hazardous material source terms are related to specific effluent streams that are, in turn, related to discharge points and, finally, are compared to the effluent monitoring system capability.

WESF was designed to convert the strontium and cesium to solid compounds and provide interim storage of these products. The B Plant facility originally separated them from the fission product waste stream following plutonium and uranium recovery from irradiated reactor fuels in the Plutonium Uranium Extraction (PUREX) Plant. The recovered, purified, and concentrated strontium and cesium solutions were then transferred to the Waste Encapsulation and Storage Facility (WESF).

The current mission of WESF is to store the cesium and strontium capsules that were manufactured at WESF, in a safe manner and in compliance with all applicable rules and regulations. The scope of WESF operations is currently limited to storage and surveillance of capsules in addition to facility maintenance activities. The capsules are expected to be stored at WESF until the year 2017.

Each liquid and gaseous effluent stream was identified, and the characteristics of the potential contaminant sources entering each stream were quantified. Data used to estimate releases during routine and upset operating conditions drew upon historical monitoring and characterization information and calculations based on potential source term information. Decontamination factors were developed for those gaseous effluent streams where engineered controls and/or barriers were in place.

4 DOE 1977, U.S. Department of Energy Organization Act of 1977, United States Department of Energy, Washington, D.C. 
A description of the current effluent monitoring system (EMS) is provided to compare the operational capabilities of the EMS to both applicable requirements and the characteristics of the effluent streams.

The EMS was evaluated according to the following:

- Does the system operate within applicable requirements?

- Do the instrument specifications match up with the characteristics of the effluent streams?

- Is the system capable of responding to upset conditions?

- If there are deficiencies, what is needed to reach compliance?

In general, the EMS is adequate for the liquid effluents. The only nonradiological monitoring parameters for which analyses are routinely performed are $\mathrm{pH}$ and flow.

Routine radiological monitoring and sampling of gaseous effluents consist primarily of only total alpha and beta analyses because potential dose to the hypothetical offsite maximum exposed individual (MEI) resulting from stack emissions is less than $0.1 \mathrm{mrem} / \mathrm{yr}$. Pursuant to 40CFR61.93, the 296-B-10 stack requires continuous emissions measurements. Under these requirements, emissions must be continuously sampled for radionuclides with the potential to contribute greater that $10 \%$ of the emission units off-site dose. Other emission points are monitored for gross alpha and gross beta only. In-line monitoring for gross radioactivity is generally adequate for process operation control for gaseous effluents in order to identify potential upset conditions. However, in-line gross radioactivity monitoring is not sufficient to meet National Emissions Standards for Hazardous Air Pollutants (EPA 1991a) regulatory requirements for the 296-B-10 Stack only; and therefore, continuous sampling and analysis of samples is required.

Additionally, if spills or upsets occur, sampling should be conducted for any contaminants that have the potential to exceed regulatory limits 


\section{CONTENTS}

1.0 FACILITY EFFLUENT MONITORING PLAN ....................................................................... 1-1

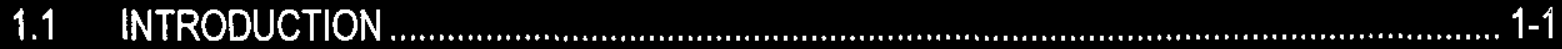

1.1.1 Policy................................................................................................... 1-1

1.1.2 Purpose ....................................................................................................... $1-1$

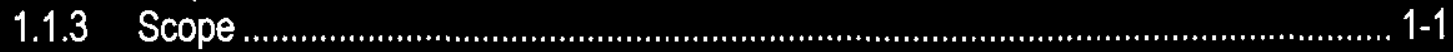

1.1.4 Discussion ...................................................................................................... 1-2

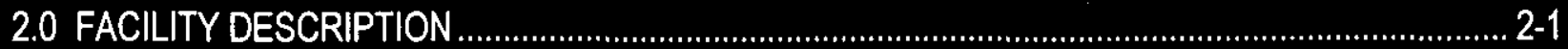

2.1 BRIEF FACILITY PHYSICAL DESCRIPTION ........................................................... $2-1$

2.1.1 The 225-B Building (WESF) ........................................................................... 2-2

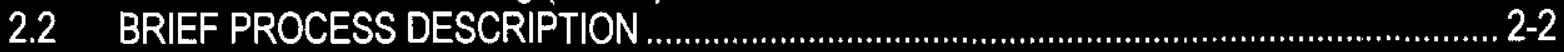

2.2.1 Liquid Effluents ......................................................................................... $2-2$

2.2.1.1 WESF Liquid Effluent (WLE) ................................................................ 2-2

2.2.1.2 WESF Sanitary Sewer Systems (SSS) ..................................................... 2-3

2.2.1.3 WESF Cooling Water (WCW) .............................................................. 2-3

2.2.2 Air Effluents ................................................................................................ 2-4

2.2.2.1 WESF Stack................................................................................. 2-4

2.3 IDENTIFICATION AND CHARACTERIZATION OF POTENTIAL SOURCE TERMS ............. 2-5

2.3.1 Liquid Effluents ............................................................................................... 2-5

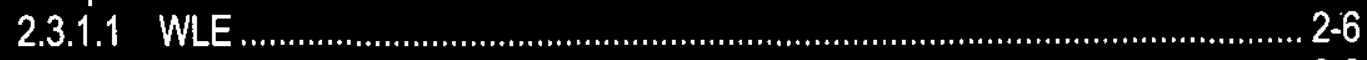

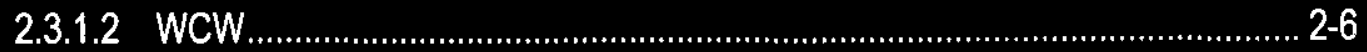

2.3.2 Air Effluents ................................................................................................... 2-6

2.3.2.1 WESF Stacks................................................................................ 2-6

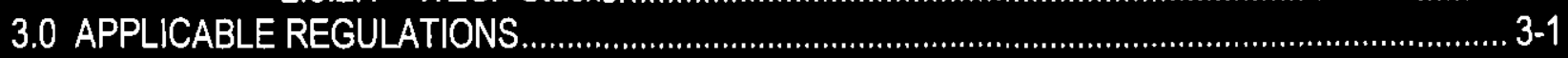

3.1 U.S. DEPARTMENT OF ENERGY ORDERS ..................................................... $3-1$

3.1.1 General Environmental Protection Program ......................................................... 3-1

3.2 FEDERAL REGULATIONS ................................................................................. $3-1$

3.2.1 National Emission Standards for Hazardous Air Pollutants (40 CFR 61, Subpart H). 3-1

3.2.2 State Operating Permit Program (40 CFR 70) ...................................................... 3-6

3.2.3 Identification and Listing of Hazardous Waste (40 CFR 261) ................................. 3-6

3.2.4 Designation, Reportable Quantities, and Notification (40 CFR 302) ......................... 3-6

3.3 INDUSTRY STANDARDS UNDER AMERICAN NATIONAL STANDARDS INSTITUTE ....... 3-7

3.3.1 Guide to Sampling Airborne Radioactive Materials in Nuclear Facilities (ANSI

N13.1-1969).................................................................................................. 3-7

3.3.2 Specification and Performance of Onsite Instrumentation for Continuously Monitoring Radioactivity in Effluents (ANSI N42.18-1980) ...................................................... 3-7

3.4 WASHINGTON STATE REGULATIONS ................................................................... 3-7

3.4.1 Air Operating Permit Program (WAC 173-401 ...................................................... 3-7

3.4.2 Ambient Air Quality Standards and Emission Limits For Radionuclides (WAC 173-480)

3.4.3 Radiation Protection - Air Emissions (WAC 246-247) ....................................

3.4.4 Water Quality Standards for Groundwater (WAC 173-200) ..................................... 3-8

3.4.5 State Waste Discharge Permit Program (WAC 173-216) ......................................... 3-8

3.4.6 Dangerous Waste Regulations (WAC 173-303) .................................................. 3-8 
3.5 LOCAL REGULATIONS ..........................................................................................

3.5.1 Benton County Air Authority (BCAA) ............................................................... 3-9

3.6 AIR EMISSIONS.............................................................................................

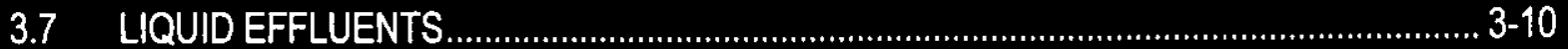

4.0 IDENTIFICATION AND CHARACTERIZATION OF EFFLUENT STREAMS .................................. 4-1

4.1 IDENTIFICATION AND CHARACTERIZATION OF SOURCE TERMS CONTRIBUTING TO EACH EFFLUENT STREAM ......................................................................................... 4-1

4.1.1 Liquid Effluents............................................................................................ 4-1

4.1.1.1 WESF Liquid Effluent (WLE) ................................................................. 4-1

4.1.1.2 Sanitary Sewers ..................................................................................... 4-1

4.1.1.3 WCW............................................................................................... 4 -1

4.1.2 Air Effluents ............................................................................................... 4-2

4.1.2.1 WESF Stack .................................................................................... 4-2

4.2 ROUTINE OPERATING CONDITIONS ............................................................... 4-2

4.2.1 Liquid Effluents .............................................................................................. 4-2

4.2.1.1. WLE ............................................................................................. $4-2$

4.2.1.2 WCW............................................................................................. $4-2$

4.2.2 Air Effluents ................................................................................................. 4-3

4.2.2.1 WESF Stacks .................................................................................. 4-4

4.3 UPSET OPERATING CONDITIONS ...................................................................... 4 .

4.3.1 Liquid Effluents ............................................................................................... 4-5

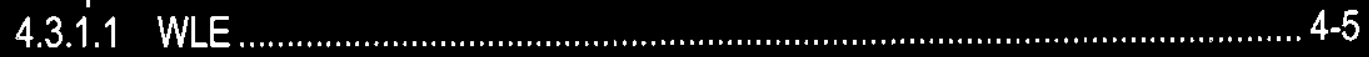

4.3.1.2 WCW........................................................................................ 4 -5

4.3.2 Air Effluents ............................................................................................. 4-6



4.3.2.2 Upset Scenarios..................................................................................... 4-6

5.0 EFFLUENT POINT OF DISCHARGE DESCRIPTION ............................................................. 5-1

5.1 LIQUID EFFLUENTS........................................................................................ 5-1

5.1.1 The WESF Liquid Effluent to TEDF via F-Line .................................................... 5-1

5.1.2 WESF Cooling Water (WCW) ........................................................................ 5-1



5.2.1 The Waste Encapsulation Storage Facility Stack ................................................. 5-2

5.2.1.1 The 296-B-5 Stack ........................................................................ 5-2

5.2.1.2 The 296-B-10 Stack ........................................................................ 5-2

5.2.1.3 The 296-B-13 Stack ........................................................................... 5-2

5.2.2 Waste Encapsulation Storage Facility Emergency Jet (296-B-12) ........................... 5-2

6.0 EFFLUENT MONITORINGISAMPLING SYSTEM DESIGN CRITERIA ........................................ 6-1

6.1 LIQUID EFFLUENT DESIGN CRITERIA ................................................................... 6 -1

6.1.1. WESF Cooling Water (WCW) ........................................................................ 6-1

6.1.2 WLE................................................................................................... $6-1$

6.2 Air Effluent Design Criteria ....................................................................................... 6-2

6.2.1 The 296-B-10 System................................................................................ 6-2

7.0 CHARACTERIZATION OF THE CURRENT EFFLUENT MONITORING SYSTEM .......................... $7-1$

7.1 INSTRUMENTATION DESCRIPTION .....................................................................

7.2 TECHNICAL SPECIFICATIONS PERTAINING TO EFFLUENT MONITORING SYSTEM ....7-1

7.2.1 Liquid Effluents................................................................................................ $7-1$ 


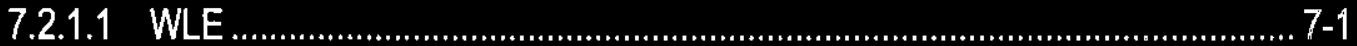

7.2.1.2 Sanitary Sewers ...................................................................................

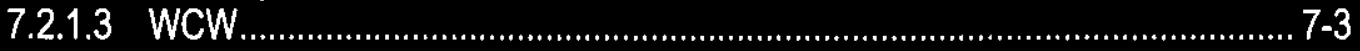

7.2.2 Air Effluents ................................................................................................... $7-4$

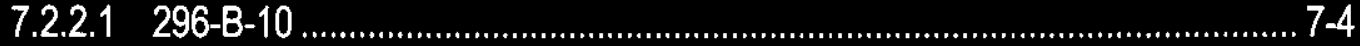

7.3 ALTERNATIVE MONITORING AND ASSESSMENT METHODS ....................................... $7-4$

8.0 HISTORICAL MONITORINGISAMPLING DATA FOR EFFLUENT STREAMS ............................... 8-1

8.1 NORMAL CONDITIONS .....................................................................................

8.1.1 Liquid Effluent Streams ................................................................................ 8-1

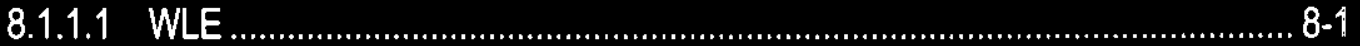

8.1.1.2 Sanitary Sewers................................................................................ 8-2

8.1.1.3 French Drains ......................................................................................... 8-2

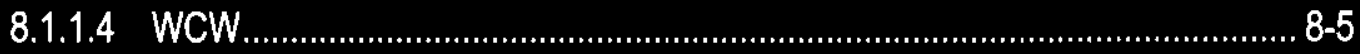

8.1.2 Air Effluent Streams.................................................................................. 8-5

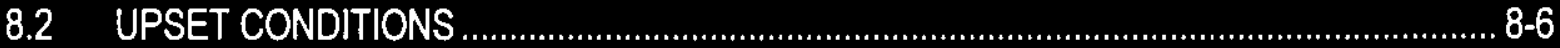

9.0 SAMPLE ANALYSIS ..............................................................................................................

9.1 ANALYTICAL LABORATORY AND PROCEDURES..................................................... $9-1$

9.1.1 Record Sample Exchange .................................................................................. 9-1

9.1.2 CAM Filter Exchange .......................................................................................... 9-1

9.1.3 Sample Data Examination and Delivery ............................................................. 9-1

9.1.4 Laboratory Sample Analysis Instructions............................................................ 9-2

9.1.5 Laboratory Analysis ........................................................................................ 9-2

9.1.6 Laboratory Procedures ...................................................................................... 9-2

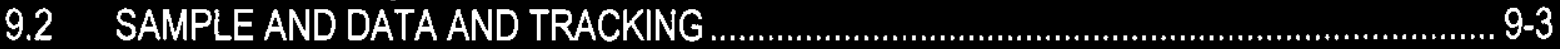

9.3 U.S. DEPARTMENT OF ENERGY ANALYTICAL AND LABORATORY GUIDELINES.......... 9-3

10.0 NOTIFICATIONS AND REPORTING REQUIREMENTS ...................................................... 10-1

10.1 REQUIREMENTS.......................................................................................... 10-1

10.1.1 Occurrence Identification and Immediate Response ............................................ 10-1

10.2 OCCURRENCE CATEGORIZATION ........................................................................ 10-1

10.2.1 Radioactive Releases ................................................................................ 10-2

10.2.1.1 Emergency .................................................................................... 10-2

10.2.1.2 Unusual Occurrence .............................................................................. 10-2

10.2.1.3 Off-Normal ................................................................................... 10-2

10.2.2 Release of Hazardous Substances/Regulated Pollutants/Oil ................................ 10-3

10.2.2.1 Emergency ........................................................................................... 10-3

10.2.2.2 Unusual Occurrence .............................................................................. 10-3

10.2.2.3 Off-Normal ....................................................................................... 10-3

10.2.3 Discovery of Hazardous Material Contamination Due to U.S. Department of Energy Operations .................................................................................................... 10-4

10.2.3.1 Emergency ......................................................................................... 10-4

10.2.3.2 Unusual Occurrence ........................................................................... 10-4

10.2.3.3 Off-Normal .................................................................................... 10-5

10.2.4 Agreement and Compliance Activities ............................................................... 10-5

10.2.4.1 Unusual Occurrence .......................................................................... 10-5

10.2.4.2 Off-Normal ..................................................................................... 10-5

10.2.5 Ecological Resources .............................................................................. 10-5 
10.2.5.1 Unusual Occurrence 10-5

11.0 INTERFACE WITH THE OPERATIONAL ENVIRONMENTAL MONITORING PROGRAM.

11.1 DESCRIPTION

11.2 PURPOSE

11.3 BASIS

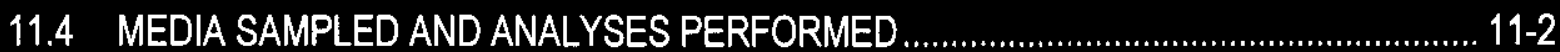

11.5 LOCATIONS ............................................................................................................ 11-2

11.6 PROGRAM REVIEW .......................................................................................... 11-3



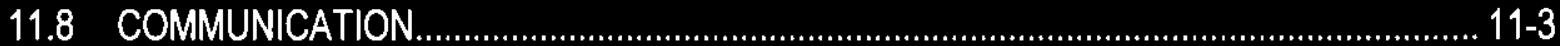

11.9 REPORTS

12.0 QUALITY ASSURANCE

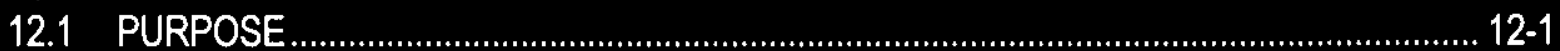

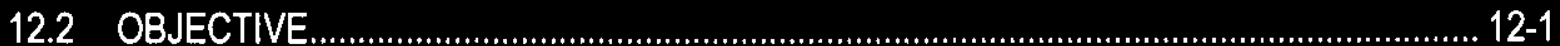



13.0 INTERNAL AND EXTERNAL PLAN REVIEW .................................................................... 13-1

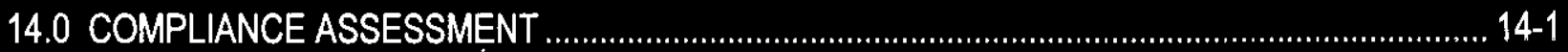

14.1 COMPLIANCE ASSESSMENT COMPARISONS ................................................ 14-1

14.1.1 Comparison of Instrument Specifications with Required Standards ........................ 14-1

14.1.1.1 Liquid Streams ...................................................................................... 14-1

14.1.1.2 Air Effluents......................................................................................... 14-1

14.1.2 Comparison of Instrument Specifications with Monitoring Criteria .......................... 14-3

14.1.3 Comparison of Instrument Specifications with Effluent Characteristics ................... 14-3

14.1.4 Comparison of Projected Effiuent Characteristics with Historical Data .................... 14-3

14.1.5 Comparison of Effluent Monitoring Capabilities with Regulatory and Contractor Requirements ................................................................................................... 14-3



14.3 SYSTEM UPGRADES REQUIRED FOR COMPLIANCE ........................................... 14-3

15.0 SUMMARY AND CONCLUSIONS ............................................................................... 15-1

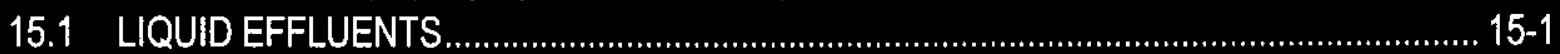

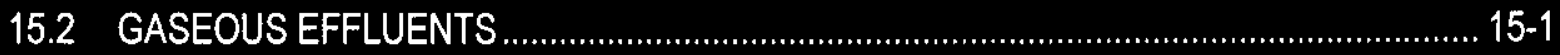

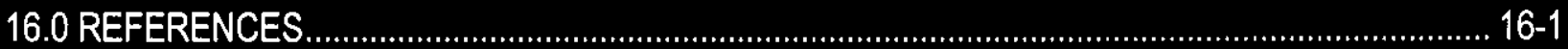


HNF-4200, Rev. 0

\section{LIST OF TABLES}

Table 1-1 Effluents Included in This FEMP ................................................................................ 1-2

Table 2-1 WESF Structures and their Functions. ......................................................................... 2-1

Table 2-2 Qualitative Assessment of Characterized Source Terms. ......................................................... 2-6

Table 2-3 Calculated Cesium and Strontium Inventories for K-3 Ventilation Duct..................................... 2-7

Table 3-1 Applicable Regulations, Standards, and Permits ................................................................... 3-3

Table 4-1 Maximum Annual Average Calculated Radionuclide-Specific Stack Releases for Routine Operations.................................................................................................................... 4-4

Table 4-2 Comparison of Routine Stack Releases With Regulatory Limits for the 296-B-10 Stack. ......... 4-4

Table 5-1 Liquid Effluent Discharge Points ...................................................................................... 4-1

Table 5-2 Air Effluent Discharge Points ......................................................................................... 5-2

Table 7-1 Liquid Effluent Monitoring Instrumentation WESF Liquid Effluent. ......................................... 7-2

Table 7-2 Liquid Effluent Monitoring Instrumentation WESF Cooling Water ............................................. 7-2

Table 7-3 Primary Record Sampler Located at the 225-B Building (B-748) ........................................... 7-3

Table 8-1 Statistical Data for the WESF Liquid Effluent (WLE) TEDF Tie-In.......................................... 8-3

Table 8-2 Statistical Data for the WESF Cooling Water (WCW) TEDF Tie-In. ....................................... 8-4

Table 8-3 Annual Radionuclide Emissions from the 296-B-10 Stack. .................................................. 8-5

Table 8-4 WESF Air Effluent System Radiological Data a................................................................. 8-6

Table 9-1 Minimum Detectable Concentrations for Specific Radionuclides as Measured in Air Samples. 9-2

Table 9-2 Data Analyses and Statistical Treatment ............................................................................ 9-4

Table 14-1 Regulatory Compliance of WESF Liquid Effluent Stream Monitors..................................... 14-2

Table 14-2 Comparison of Regulatory and Lab Analytical Detection Limits .......................................... 14-2 
HNF-4200, Rev. 0

\section{LIST OF TERMS}

$\begin{array}{ll}\text { ACL } & \text { administrative control limits } \\ \text { ACV } & \text { administrative control values } \\ \text { ANSI } & \text { American National Standards Institute } \\ \text { ALARA } & \text { as low as reasonably achievable } \\ \text { AMU } & \text { Aqueous Makeup Unit } \\ \text { ASTM } & \text { American Society of Testing and Materials } \\ \text { BAT } & \text { best available technology } \\ \text { BCE } & \text { B Plant chemical sewer } \\ \text { BCP } & \text { B Plant process condensate } \\ \text { BCS } & \text { B Plant steam condensate } \\ \text { CAM } & \text { continuous air monitor } \\ \text { CAW } & \text { current acid waste } \\ \text { CBC } & \text { B Plant cooling water } \\ \text { CDI } & \text { continuous deionizing unit } \\ \text { CERCLA } & \text { Comprehensive Environmental Response, Compensation, and Liability Act of } \\ & \text { 1980 } \\ \text { CFR } & \text { Code of Federal Regulation } \\ \text { CW } & \text { concentrated waste } \\ \text { CY } & \text { calendar year } \\ \text { CWA } & \text { Clean Water Act of 1977 } \\ \text { DAC } & \text { derived air concentration } \\ \text { DCG } & \text { derived concentration guide } \\ \text { DF } & \text { decontamination factor } \\ \text { DOE } & \text { U.S. Department of Energy } \\ \text { DOS } & \text { Di-2-Ethylhexl Sebacate } \\ \text { DP } & \text { differential pressure } \\ \text { ECL } & \text { environmental control limit } \\ \text { EDE } & \text { effective dose equivalent } \\ \text { EES } & \text { Environmental Engineering Studies } \\ \text { EF } & \text { exhaust fan } \\ \text { EMP } & \text { environmental monitoring plan } \\ \text { EMS } & \text { effluent monitoring system } \\ \text { EPA } & \text { U.S. Environmental Protection Agency } \\ \text { ES\&H } & \text { environmental protection, safety, and health } \\ \text { FEMP } & \text { facility effluent monitoring plan } \\ \text { FPMCS } & \text { Facility Process Monitoring Control System } \\ \text { HDPE } & \text { high density polyethylene pipe } \\ \text { HEPA } & \text { high-efficiency particulate air filter } \\ \text { HVAC } & \text { heating, ventilation, and air conditioning } \\ \text { LLW } & \text { low-level waste } \\ \text { LLWC } & \text { B Plant low-level waste concentrator } \\ \text { MEI } & \text { maximum exposed individual } \\ \text { MOU } & \text { Memorandum of Understanding } \\ \text { MRP } & \text { Management Requirements and Procedures } \\ & \end{array}$


HNF-4200, Rev. 0

\section{LIST OF TERMS (continued)}

\begin{tabular}{ll} 
MSL & mean sea level \\
NBS & National Bureau of Standards \\
NCAW & neutralized current acid waste \\
NESHAP & National Emission Standards for Hazardous Air Pollutants \\
NPDES & National Pollution Discharge Elimination System \\
OEC & Operations and Engineering Contractor \\
OIU & Operator Interface Unit \\
ONC & Occurrence Notification Center \\
PNL & Pacific Northwest Laboratories \\
POTW & Public-Owned Treatment Works \\
PRV & pressure-reducing valve \\
PUREX & Plutonium Uranium Extraction \\
QA & quality assurance \\
QAPP & Quality Assurance Project Plan \\
RCG & Radioactive Concentration Guides \\
RL & U.S. Department of Energy Field Office, Richland \\
RQ & reportable quantities \\
RTRP & reinforced thermosetting resin pipe \\
SAR & safety analysis report \\
SARA & Superfund Amendments and Reauthorization Act of 1986 \\
SPCC & Spill Prevention Control and Countermeasures Plan \\
SSS & B Plant sanitary sewer system \\
SWP & special worker protection \\
TLD & thermoluminescent dosimeter \\
TLV & threshold limit value \\
TOC & total organic carbon \\
VCP & vitrified clay pipe \\
VVS & vessel ventilation system \\
WAC & Washington Administrative Code \\
WESF & Waste Encapsulation Storage Facility \\
WHC & Westinghouse Hanford Company \\
& \\
& \\
\hline
\end{tabular}




\section{METRIC CONVERSION CHART}

\begin{tabular}{|c|c|c|}
\hline \multicolumn{3}{|c|}{ INTO METRIC } \\
\hline If you know & Multiply by & To get \\
\hline \multicolumn{3}{|c|}{ Length } \\
\hline inches & 2.54 & centimeters \\
\hline feet & 30.48 & centimeters \\
\hline feet & 0.3048 & meters \\
\hline \multicolumn{3}{|c|}{ Volume } \\
\hline gallons & 3.786 & liters \\
\hline cubic feet & 0.02832 & cubic meters \\
\hline \multicolumn{3}{|c|}{ Weight } \\
\hline ounces & 0.02835 & kilogram \\
\hline pounds & 0.45359 & kilogram \\
\hline \multicolumn{3}{|c|}{ Temperature } \\
\hline Fahrenheit & Subtract 32 then multiply by $5 / 9$ ths & Celsius \\
\hline \multicolumn{3}{|c|}{ Pressure } \\
\hline inches water & 1.87 & $\mathrm{~mm} \mathrm{Hg}$ \\
\hline inches water & 249 & Pascal (Pa) \\
\hline \multicolumn{3}{|c|}{ OUT OF METRIC } \\
\hline \multicolumn{3}{|c|}{ Length } \\
\hline centimeters & 0.3937 & inches \\
\hline meters & 3.28 & feet \\
\hline \multicolumn{3}{|c|}{ Volume } \\
\hline milliliters & $1.247 \times 10^{-3}$ & cubic feet \\
\hline liters & 0.264 & gallons \\
\hline cubic meters & 35.31 & cubic feet \\
\hline \multicolumn{3}{|c|}{ Temperature } \\
\hline Celsius & Multiply by $9 / 5$ ths, then add 32 & Fahrenheit \\
\hline \multicolumn{3}{|c|}{ Pressure } \\
\hline $\mathrm{mm} \mathrm{Hg}$ & 0.5353 & inches water \\
\hline Paschal (Pa) & $4.02 \times 10^{-3}$ & inches water \\
\hline
\end{tabular}


HNF-4200, Rev. 0

\section{FACILITY EFFLUENT MONITORING PLAN FOR WESF}

\subsection{FACILITY EFFLUENT MONITORING PLAN}

\subsection{INTRODUCTION}

This section provides information on the policy, purpose, and scope of a facility effluent monitoring plan (FEMP).

\subsubsection{Policy}

It is the policy of the U.S. Department of Energy (DOE) and its contractor, the Fluor Daniel Hanford Company to conduct operations in an environmentally safe and sound manner and to perform effluent monitoring to determine whether the public and the environment are adequately protected during DOE operations and whether operations are in compliance with DOE and other applicable federal, state, and local environmental and health protection standards and requirements. It is also DOE and DOE contractor policy that effluent monitoring programs meet high standards of quality and credibility.

\subsubsection{Purpose}

The purpose of this plan is to fulfill DOE requirement DOE 5400.1 (DOE 1991c) for a FEMP to exist for each site, facility, or process that uses, generates, releases, or manages significant pollutants of radioactive or hazardous materials that could affect public and employee safety and the environment. This document is specifically intended to meet this requirement for WESF.

\subsubsection{Scope}

This document includes program plans for monitoring and characterizing radioactive and nonradioactive hazardous materials discharged in WESF facility effluents. This plan includes complete documentation for gaseous and liquid effluent monitoring systems for both radioactive and nonradioactive hazardous components that could be discharged under routine and/or upset operating conditions. 
The plan is intended to provide a mechanism by which Fluor Daniel Hanford and RL can ensure the WESF Effluent Monitoring Program will satisfy the following program objectives to (DOE 1991c):

- Verify compliance with applicable federal, state, and local effluent regulations and standards and DOE orders

- Determine compliance with commitments made in environmental impact statements, environmental assessments, or other official documents

- Evaluate the effectiveness of treatment and control systems

- Support permit revision and/or reissuance

Detect and characterize unplanned releases Identify potential environmental problems.

The WESF effluents included in this FEMP are listed in Table 1-1.

Table 1-1 Effluents Included in This FEMP

\begin{tabular}{|l|l|}
\hline \multicolumn{1}{|c|}{ Liquid } & \multicolumn{1}{c|}{ Gaseous } \\
\hline $\begin{array}{l}\text { WESF Cooling Water (WCW) } \\
\text { WESF Liquid Effluent (WLE) }\end{array}$ & 296-B-10 Stack \\
\hline
\end{tabular}

\subsubsection{Discussion}

Regulations goveming airborne radioactive emissions are given in 40 Code of Federal Regulations (CFR) Part 61 [National Emission Standards for Hazardous Air Pollutants (NESHAPs)] (EPA 1991a). Under NESHAPs, the U.S. Environmental Protection Agency (EPA) is promulgating a NESHAPs mandating that radionuclide emissions from each DOE site not exceed $10 \mathrm{mrem} / \mathrm{yr}$ effective dose equivalent (EDE) to the maximally exposed individual. The entire Hanford site represents the DOE Site Facility and must therefore meet the $10 \mathrm{mrem} / \mathrm{yr}$ standard. Subpart $H$ of the NESHAPs regulations requires that radionuclide emission rates from stacks and vents be continuously measured at all release points with the potential to discharge radionuclides into the air in quantities that could cause an EDE in excess of 1 percent of the 10 $\mathrm{mrem} / \mathrm{yr}$ EDE standard. Furthermore, all radionuclides that could contribute greater than 10 percent of the potential EDE for each release point must be measured; or, with prior EPA approval, alternative methods may be used. When determining whether a FEMP is required for a specific facility, engineered emission controls between the point of generation and the discharge point are not to be considered. 
Characterization of the radioactive and nonradioactive constituents in each WESF effluent stream provides the underlying rationale for the effluent monitoring program discussed in this plan. Regulations such as NESHAPs (EPA 1991a) and the Clean Water Act of 1977 (CWA 1977) provide guidance on the adequacy of effluent monitoring. Characterization of hazardous waste at the point of generation is required by 40 CFR 261.3(b) (EPA 1991b). While this requirement is for dangerous waste only, this plan addresses all major potential contaminants at the point of generation in order to assess the effectiveness of engineered and administrative barriers, as well as the consequences of upset releases, and to ensure that effluent monitoring programs address all pertinent constituents.

The plan tracks the constituents from their generation to the discharge points and considers the effectiveness of each barrier/control device. The effectiveness of each control device is measured in terms of its decontamination factor (DF). The DFs are based on vendor specifications, operational data, and by conservative projection.

For nonradioactive effluents, the risk to the public and the environment is also controlled by limiting the quantities of materials released. Requirements are frequently based on regulatory or technology-based release limits for the materials.

The FEMPs are required for facilities if the total projected EDE to any member of the public from radionuclide airborne emissions at the facility exceeds $0.1 \mathrm{mrem} / \mathrm{yr}$ from any one discharge point or if any one regulated material discharged over a 24-h period from a facility exceeds 100 percent of the Comprehensive Environmental Response, Compensation, and Liabilty Act of 1980 (CERCLA) Reportable Quantity (RQ) as listed in Title 40 Code of Federal Regulations Part 302.4, "Designation of Hazardous Substances" (EPA 1991c). A FEMP is required for a facility if the liquid effluent stream contains measurable radionuclide concentrations and the concentrations exceed the drinking water standards. The FEMPs are self-supporting in-depth documents that detail the effluents, the effluent discharge points, the monitoring systems, the sample protocol, and the controls of the facility. 


\subsection{FACILITY DESCRIPTION}

The WESF Facility is in the 200 East Area of the Hanford Site, located in the south central region of Washington State.

WESF was designed to convert the strontium and cesium to solid compounds, encapsulate and provide interim storage for these products. The Waste Encapsulation Storage Facility's mission is to maintain the 150 million curries of $\mathrm{Cs} / \mathrm{Sr}$ in a safe, environmental, and cost effective storage.

This section provides a physical description of WESF, process descriptions applicable to this FEMP, and identification and characterization of potential source terms.

\subsection{BRIEF FACILITY PHYSICAL DESCRIPTION}

WESF main and supporting structures are located in $200 \mathrm{E}$. south of Atlanta Avenue and North of $7^{\text {th }}$ St.

The WESF complex building is 225-B. It also includes various support buildings as listed in Table 2-1. The WESF was completed in 1974.

Table 2-1 WESF Structures and their Functions.

\begin{tabular}{|l|l|}
\hline \multicolumn{1}{|c|}{ Facility } & \multicolumn{1}{c|}{ Function } \\
\hline 151-Pit & Flow and pH monitoring of liquid effluent to TEDF F-Line \\
\hline 225-B WESF & Storage of strontium and cesium capsules \\
\hline 225-BC Compressor Building & Compressor building for WESF and B Plant \\
\hline 225-BD Sample Building & $\begin{array}{l}\text { Inactive for sampling. Contains instrumentation for K3 and is } \\
\text { used for storage. }\end{array}$ \\
\hline 225BE Shop & Provides area for maintenance shops. \\
\hline 225-BF Compressor Building & Add on to 225-BC \\
\hline $\begin{array}{l}\text { 225 BG Cooling water to WESF } \\
\text { pools }\end{array}$ & $\begin{array}{l}\text { Provides area for treatment and monitoring of cooling water } \\
\text { system for the WESF pools. }\end{array}$ \\
\hline 272-B Operations Support & Provides area for operations personnel. \\
\hline 272-BA Material Storage Building & Provides area for material storage. \\
\hline 272-BB Material Storage Building & Provides area for material storage. \\
\hline 282-B Pump House & Deep well pump for backup raw water supply \\
\hline 282-BA Pump House & Deep well pump for backup raw water supply \\
\hline
\end{tabular}


HNF-4200, Rev. 0

\subsubsection{The 225-B Bullding (WESF)}

The 225-B Building is a two-story structure $157 \mathrm{ft} \mathrm{long,} 97 \mathrm{ft}$ wide, and $40 \mathrm{ft}$ high (outside dimensions). The building has a combined floor area of approximately $20,000 \mathrm{ft}^{2}$, including $14,000 \mathrm{ft}^{2}$ on the first floor and $6000 \mathrm{ft}^{2}$ on the second floor.

The floor plan is partitioned into the following functional areas: (1) the process hot cell area, (2) the hot cell service areas, (3) the operating areas, (4) the building service areas, and (5) the storage pool area. The partitioned floor plan regulates the flow of personnel and material traffic throughout the building and limits access in areas where potential contamination or radiation exposure is high.

\subsection{BRIEF PROCESS DESCRIPTION}

There are currently no production activities at WESF. However, WESF remains operational, providing surveillance of the cesium and strontium capsules, radiological inventory and effluents. These operations include temporary storage of low-level radioactive waste, various maintenance activities at the facility, and storage and transfer of hazardous materials inside and outside of WESF. The WESF complex will continue these operations in a safe, cost-effective manner for the life of the facility.

In the past, the cesium and strontium feed materials to WESF were purified and concentrated in B Plant before being processed in WESF. The cesium process system converted aqueous cesium carbonate feed solution to cesium chloride. The strontium process system converted strontium nitrate solution to strontium fluoride. Waste streams were returned to the B Plant for recycling. The products were doubly encapsulated and stored in underwater storage pools. Some of these products have been shipped offsite.

Additional information on the effluents pertaining to this FEMP is contained in the following subsections.

\subsubsection{Liquid Effiluents}

Two liquid effluent streams evolve from WESF operations; the liquid effluent transferred to TEDF "F" Line (WESF Liquid Effluent (WLE), formerly referred to as the B Plant Chemical Sewer (BCE)), and the liquid effluent transferred to TEDF "E" Line (WESF Cooling Water (WCW)). Sanitary water is also discharged from the facilities and will be discussed with the previously mentioned streams even though the sanitary sewer system (SSS) is not considered to have the potential for release of contaminated liquids to the environment.

\subsubsection{WESF Liquid Efiluent (WLE)}

This stream is routed to the Treated Effluent Discharge Facility. The present WLE does not communicate with the radioactive processing areas of WESF. There are also administrative controls that prevent the WLE from coming in contact with chemical discharges.

The WLE can also receive steam condensate, cooling water, and HVAC unit wash water, sanitary water, and other effluents from WESF and the 225-BC Air Compressor Building. 
HNF-4200, Rev. 0

The WLE ties into TEDF pump station \#2, located east of the intersection of Baltimore Avenue and Atlanta. The WLE discharges to pump station \#2 at an average flowrate of 5-10 gpm. From the tie-in to TEDF, the WLE is a main 8-in.-dia. high density polyethylene pipe (HDPE). The 8-in.-dia. pipe (F Line) extends west along the south side of Atlanta Avenue and is then routed south to the WLE 151 pit where monitoring occurs. The WLE is then routed south from the 151 pit to Manhole 14.

The 10" RTRP header then extends west, parallel to the 221-B Building, to Manhole 10, which is located northwest of the 271-B Building. The 10-in. RTRP header traverses south to manhole 8 . From Manhole 8, a 10in. VCP header extends north to Manhole 7, crosses west to Manhole 6, turns and extends south to Manhole 5. This 10-in. VCP header collects steam condensate from the 225-B HVAC system and 225-BC Compressor Building and effluent from AMU tank overflow and floor drains located in the WESF. This 10-in. VCP header also receives effluent from two 4-in. yard drains located at the southwest corner of the 225-B Building. From Manhole 5, the 10-in. VCP transverses east to Manhole 2 where it connects to an 8 -in. VCP header and continues to Manhole 1, 10 feet east of the 222-B Building. This section of header receives rain water from a yard drain at Manhole 5 and from two street drains located north of 224-8 that discharge at Manhole 3.

\subsubsection{WESF Sanitary Sewer Systems (SSS)}

Sanitary waste generated within the WESF complex is drained to septic tank-field systems within the 200 East Area. This disposal adheres to Benton County Health Department Guidelines (RHO 1986).

A new sanitary sewer system is installed in the 200 East area. Upon completion of this project, the SSS 2607-E3 septic tank and drain field were abandoned in place and the sanitary sewage effluent from WESF is routed to a pressurized sewer pump station located north of the $221 \mathrm{~B}$ building and Atlanta Avenue. Liquid sewage is routed to the 200 East Drain fields located near Baltimore Avenue.

\subsubsection{WESF Cooling Water (WCW)}

A Closed Loop Cooling System (CLCS) was installed early in 1997 for the pool cell heat exchanger cooling water to augment the once-through raw water cooling system currently in place. The CLCS system provides the primary source of cooling water to the pool cell heat exchangers so that the functional requirements related to cooling the pool cell water can still be met for a fully loaded pool cell. With the CLCS in operation, the liquid effluent discharge rate associated with the cooling system decreased from over $3,785 \mathrm{~L} / \mathrm{min}(1,000$ gal/min) to approximately $114 \mathrm{~L} / \mathrm{min}(30 \mathrm{gal} / \mathrm{min})$. Liquid effluent is routed to the Treatment Effluent Disposal Facility (TEDF).

The main return line for the CLCS ties into the $25.4 \mathrm{~cm}$ (10-inch) raw water pipe just outside of the $225 \mathrm{~B}$ Building. The supply of chilled water to individual pool cell heat exchangers was made through existing cooling water piping. The cooling water return header was routed to the new CLCS supply line. Water entering the CLCS goes to three wet-surface fluid coolers (cooling towers), which are designed to provide sufficient cooling capacity to maintain the pool cell temperatures below the limits established in the facility Authorization Basis. Due to evaporation from treated water circulating in the cooling towers, a cooling water effluent stream drains 
HNF-4200, Rev. 0

approximately $114 \mathrm{~L} / \mathrm{min}$ ( $30 \mathrm{gal} / \mathrm{min}$ ) from the three cooling towers to maintain proper chemical and mineral concentrations. This effluent is routed to the TEDF.

If the CLCS fails, the original raw water supply to the heat exchangers can be reconnected. In that case, the cooling water effluent stream is also capable of handling 4,540 L/min $(1,200 \mathrm{gal} / \mathrm{min})$ of raw water diverted from the CLCS supply line. Normal electrical power to the CLCS is supplied from a new motor control center connected to a new transformer fed directly from the $13.8-\mathrm{kV}$ line to the $\mathrm{C} 8-\mathrm{S} 26$ substation. There is also a standby diesel generator with automatic switchover in case of normal power failure. A local control unit building houses the new motor control center, the closed loop circulation pumps, a programmable logic controller (PLC), a fluid cooler chemical addition system, and a cooling water effluent stream sump. Instrumentation systems provide remote readout for CLCS flow, temperature, and pressure, and the PLC is programmed to indicate both total system failure and individual cooler failure.

The WCW discharges to TEDF. This discharge stream is monitored continuously for flow, $\mathrm{pH}$, conductivity and temperature. Samples are also taken bi-monthly and analyzed to ensure discharge parameters are within the limits established by TEDF.

\subsubsection{Air Effiluents}

The air effluent release points for the WESF facility is listed below.

Stack

- 296-B-10 WESF Stack

\subsubsection{WESF Stack}

Location of WESF stack is south of 225-B. The paragraphs below provide a brief description of this stack and associated HVAC systems.

296-B-10 Stack (WESF)--The 296-B-10 Stack is a 42-in.-dia. by 70-ft atmospheric discharge stack and handles the exhaust of the K1 and K3 HVAC systems of the 225-B (WESF) Building. The ventilation system of WESF is designed to provide airflow patterns so that air movement throughout the building is from areas of lesser radioactivity to areas of greater radioactivity. All potentially contaminated areas are maintained at a negative pressure with respect to the atmosphere so that air flows into the building at all times. The K-1 HVAC system provides ventilation for the potentially contaminated areas such as operating and service areas with air being filtered through the K-1 filter building. The K-3 HVAC system provides ventilation for the highly contaminated process cells and the canyon area. The K-4 HVAC system provides ventilation supply to the pool cell area, and the air is filtered through the K-1 filter building. The K2 system provides ventilation to non-contaminated areas such as the offices, change rooms and AMU.

K-1 HVAC Supply and Exhaust System--The K-1 system supplies outside air on a once-through basis (no recirculation) to the 225-B support areas such as the operating gallery and service gallery. The supply air is filtered, heated or cooled appropriately, and distributed through a duct network to the serviced areas. A similar duct network provides an exhaust flowpath from these areas. Air balance control and optional isolation of the rooms is accomplished by installed, manually-controlled dampers in all supply and exhaust ducts. 
The exhaust of the K-1 system to the 296-B-10 Stack sequentially passes through two stages of prefilters and two stages of HEPA filters located in the K-1 filter building. The DF for normal operation of the system is conservatively rated to 1 EOO6 (RHO 1986).

K-3 HVAC Supply and Exhaust System--The K-3 supply system provides air to the canyon and hot cells. The system provides ventilation for the contaminated hot cells and canyon area and is designed to meet two sets of operating conditions: 1) routine operation, when cell cover blocks are in place; and 2) non-routine operation, when one or more cover blocks are removed from a cell to provide access to the hot cells or when the truckport coverblock is removed.

The K-3 supply air from the WESF HVAC room is distributed via ductwork to the canyon area on a once-through basis. A portion of this ventilation air enters each cell via one of two 6 -in.-dia. stainless steel ducts that are imbedded in the canyon floor. The air going to the process cells from the canyon is drawn through one stage of HEPA filters before it enters the cells. Air from each cell is exhausted through one stage of in-cell HEPA filters to a common duct. Cell exhaust dampers are provided in each cell to control the air flow and the pressure within each cell. These dampers are controlled remotely from the operating gallery. The cell ventilation air is exhausted through a 20 -in.-dia. exhaust header located under the process cells and connects to the canyon exhaust duct, which terminates at the K-3 filter. The final K-3 filtration consists of two parallel filter housings. One unit is operating, and the other is on standby. Each of the filter housings contain two banks of six HEPA filters in parallel in each bank. Pre-filter and liquid removal from the K-3 filter units is provided through a system of impingement vanes, de-entrainer pads with on-line flushing capabilities, heaters, and a buitt-in sump. The collected solution is transferred via the sump in each K-3 filter unit to TK-100. The liquid waste collected in TK-100 is pumped to the low-level waste tank TK-39-1 in the 221-B Building via the Low-Level Waste water line header. This system is capable of handling large particulate loading should some contamination migrate toward the filter housing.

K-4 HVAC Supply and Exhaust System--The K-4 system supplies ventilation air to the pool cell area on a once-through basis. The air supply equipment, which consists of a bank of filters, a preheat coil, an evaporative cooler, a reheat coil, and a centrifugal fan, are located on the roof of the storage pool area. The supply air enters the storage pool area and is distributed throughout the area. Ventilation air is exhausted from the pool cell area via a duct to the $\mathrm{K}-1$ filter building.

\subsection{IDENTIFICATION AND CHARACTERIZATION OF POTENTIAL SOURCE TERMS}

This section provides information on identifying and characterizing all potential process source terms present in the facility.

\subsubsection{Liquid Effluents}

Potential source terms for WESF liquid effluents are presented in the following sections. 
HNF-4200, Rev. 0

\subsubsection{WLE}

There is no chemical source term for the WLE. Radiological monitoring is currently performed on pool cells 9 and 10 prior to batch discharge per ICD agreement with TEDF.

\subsubsection{WCW}

The WCW consists of cooling water blowdown and, potentially, raw water used as cooling water. The contributors to the WCW are the WESF pool cell closed loop cooling system, and raw water used as single pass cooling water from the WESF pool cell heat exchangers. Discharge of single pass cooling water from the WESF pool cell heat exchangers will occur should the closed loop cooling system fail. An additional source to this stream is the monthly test of the backup well water supply system. There are no radiologically contaminated contributors to this system.

\subsubsection{Air Efiluents}

Potential source terms for WESF air effluents is presented in the following sections.

\subsubsection{WESF Stacks.}

Following are discussions of source terms for the WESF stack.

Table 2-2 Qualitative Assessment of Characterized Source Terms.

\begin{tabular}{|l|l|}
\hline \multicolumn{1}{|c|}{ Source } & \multicolumn{1}{|c|}{ Location } \\
\hline Mixed fission products in waste & Process cells and air effluent filters \\
Residues from Concentrated ${ }^{137} \mathrm{Cs}$ and & Storage vessels in process cells \\
90Sr solutions & Waste water and condensate streams \\
Microcuries of mixed fission products & \\
${ }^{137} \mathrm{Cs}$ and ${ }^{90 \mathrm{Sr}}$ & \\
\hline
\end{tabular}

Source: (RHO 1986).

296-B-10 Stack--The K-1 and K-3 exhaust systems are the contributors to the 296-B-10 Stack. Of these two systems, the K-3 is considered to have a greater potential because of the larger source term that is present in the K-3 system. Therefore, the available source terms were calculated for the K-3 exhaust system

Both cesium and strontium have been found in the K-3 exhaust duct. Radionuclide concentrations have been calculated for the K-3 duct using dose rate data accumulated during K-3 duct contamination 
HNF-4200, Rev. 0

measurements. The dose rate varied from 59 to $205 \mathrm{R} / \mathrm{h} / \mathrm{t}^{2}$. This translates to concentrations of 17 to $57 \mathrm{Ci} / \mathrm{m}^{2}$ cesium or 640 to $2000 \mathrm{Ci} / \mathrm{m}^{2}$ strontium (RHO 1985b).

The radionuclide inventories for the $K-3$ duct have been calculated using the data for the $K-3$ duct beneath $\mathrm{G}$ Cell, the inlet duct to the K-3 filter, 100 percent cesium, and 100 percent strontium. These inventories are presented in Table 2-3.

Table 2-3 Calculated Cesium and Strontium Inventories for K-3 Ventilation Duct.

\begin{tabular}{|l|c|}
\hline \multicolumn{1}{|c|}{ Percentage of Material } & Inventory (Ci) \\
\hline 38\% ${ }^{137}$ Cesium, 62\% ${ }^{\text {s0Strontium }}$ & $36,200-136,000$ \\
$85 \%$ 137Cesium, 15\% ${ }^{00}$ Strontium & $9,900-34,400$ \\
$100 \%$ 137Cesium & $1,500-5,100$ \\
$100 \%$ soStrontium & $57,500-200,000$ \\
\hline
\end{tabular}

Source: (RHO 1985b). 


\subsection{APPLICABLE REGULATIONS}

Conditions and requirements for monitoring existing or potential releases of radioactive and other chemicals to the environment are contained in DOE orders and federal, state and local laws, regulations, and permits. Table 3-1 gives a brief summary of the regulations and standards applicable to this FEMP. Since the regulations enforced by these agencies may differ, the PHMC may enforce more restrictive requirements as a matter of policy. These policies can be found in HNF-PRO-450, Air Quality Program, HNF-PRO-453, Environmental Notification and Reporting, HNF-PRO-456, Water Quality, HNF-PRO-457, Environmental Requirements Evaluation, and HNF-PRO2364, Radioactive Airborne Effluent Sampling.

\section{$3.1 \quad$ U.S. DEPARTMENT OF ENERGY ORDERS}

\subsubsection{General Environmental Protection Program}

The DOE Order 5400.1, General Environmental Protection Program, requires a written environmental monitoring plan for each site, facility, or process that uses, generates, releases, or manages significant pollutants or hazardous materials. The plan must include the rationale and design criteria for the monitoring program, as well as describe the extent and frequency of the monitoring analysis. The plan also must contain quality assurance (QA) requirements, program implementation procedures, directions for preparation and implementation of reports, and directions for identification and discussion of effluent monitoring and environmental surveillance.

The effluent monitoring portion of the plan must verify compliance with applicable regulations and DOE Orders, i.e., DOE 5400.5 Radiation Protection of the Public and the Environment. It also should evaluate the effectiveness of treatment; identify potential environmental problems; evaluate the need for remedial action or mitigation measures; support permit revision and/or reissuance; and detect, characterize, and report unplanned releases. Compliance with the requirements of DOE Order 5400.1 may be demonstrated based on calculations from monitoring and surveillance programs.

The DOE Order 5820.2A, Radioactive Waste Management (DOE 1988) establishes policies, guidelines, and minimum requirements by which the DOE manages its radioactive and mixed waste and contaminated facilities.

\subsection{FEDERAL REGULATIONS}

\subsubsection{National Emission Standards for Hazardous Air Pollutants (40 CFR 61, Subpart H)}

Subpart H, "National Emission Standards for Emissions of Radionuclides Other Than Radon from Department of Energy Facilities," (40 CFR 61) establishes exposure limits and monitoring requirements. The exposure limits, for a member of the public, from radionuclide air emissions is an EDE not to exceed $10 \mathrm{mrem} / \mathrm{year}$. Compliance with this standard is measured by calculating the highest EDE where a person resides or abides using an EPA-approved method. 


\section{HNF-4200, Rev, 0}

Emissions of radionuclides must be measured at all release points that have a potential to discharge radionuclides into the air in quantities that could cause an EDE in excess of $1 \%$ of the standard. If the EDE caused by all emissions is less than $1 \%$ of the standard, the facility is exempt from the EPA monitoring requirements. All radionuclides that could contribute greater than $10 \%$ of the potential EDE for a release point shall be measured individually. For other release points that have a potential to release radionuclides into the air, periodic confirmatory measurements shall be made to verify low emissions. 
Table 3-1 Applicable Regulations, Standards, and Permits

\begin{tabular}{|c|c|c|c|c|c|c|}
\hline Agency & Regulation, Standard, or Permit & HA & $\mathrm{HL}$ & RA & RL & Summary/Application \\
\hline \multirow{4}{*}{$\begin{array}{l}\text { U.S. } \\
\text { Department of } \\
\text { Energy (DOE), } \\
\text { Washington, } \\
\text { D.C. }\end{array}$} & DOE Order 5400.1) & $x$ & $x$ & $x$ & $x$ & $\begin{array}{l}\text { Provides general environmental } \\
\text { protection standards }\end{array}$ \\
\hline & $\begin{array}{l}\text { DOE Order } 5400.5 \\
\text { (10 CFR } 834 \text { if codified) }\end{array}$ & & & $x$ & $x$ & $\begin{array}{l}\text { Sets radioactive release standards for } \\
\text { the public and environment (dose } \\
\text { limits) }\end{array}$ \\
\hline & $\begin{array}{l}\text { DOE Order } 5820.2 \mathrm{~A} \\
\text { Radioactive Waste Management } \\
\text { (10 CFR } 835 \text { applicable also) }\end{array}$ & $x$ & $x$ & $x$ & $x$ & $\begin{array}{l}\text { Sets radioactive waste management } \\
\text { requirements. ( } 10 \text { CFR } 835 \text { requires } \\
\text { monitoring for outdoor contamination } \\
\text { near facility) }\end{array}$ \\
\hline & $\begin{array}{l}\text { DOE/EH-0173T } \\
\text { Environmental Regulatory Guide for } \\
\text { Radiological Effluent Monitoring and } \\
\text { Environmental Surveillance }\end{array}$ & & & $x$ & $x$ & $\begin{array}{l}\text { Provides guidance for effluent and } \\
\text { environmental sampling and } \\
\text { monitoring. }\end{array}$ \\
\hline \multirow{6}{*}{$\begin{array}{l}\text { U.S. } \\
\text { Environmental } \\
\text { Protection } \\
\text { Agency (EPA), } \\
\text { Washington, } \\
\text { D.C. }\end{array}$} & $\begin{array}{l}40 \text { CFR } 60 \\
\text { Standards of Performance for New } \\
\text { Stationary Sources }\end{array}$ & $x$ & & $x$ & & $\begin{array}{l}\text { Establishes monitoring requirements } \\
\text { for air pollutants. }\end{array}$ \\
\hline & $\begin{array}{l}40 \text { CFR } 61 \\
\text { NESHAP }\end{array}$ & $x$ & & $x$ & & $\begin{array}{l}\text { Sets national emission standards for } \\
\text { hazardous air pollutants (NESHAP) }\end{array}$ \\
\hline & $\begin{array}{l}40 \text { CFR } 61 \text {, Subpart } \mathrm{H} \\
\text { NESHAP for Radionuclides other than } \\
\text { Radon from Department of Energy } \\
\text { Facilities }\end{array}$ & & & $x$ & & $\begin{array}{l}\text { Sets emissions standards/monitoring } \\
\text { requirements for radionuclides }\end{array}$ \\
\hline & $\begin{array}{l}40 \text { CFR } 70 \\
\text { State Operating Permit Program }\end{array}$ & $x$ & & $x$ & & $\begin{array}{l}\text { Requires state air operating permit } \\
\text { programs (i.e., WAC 173-401) }\end{array}$ \\
\hline & $\begin{array}{l}40 \text { CFR } 261 \text { - Identification and Listing } \\
\text { of Hazardous Waste }\end{array}$ & $x$ & $x$ & & & Identifies and lists hazardous wastes \\
\hline & $\begin{array}{l}40 \text { CFR } 302 \\
\text { Designation, Reportable Quantities, } \\
\text { and Notification }\end{array}$ & $x$ & & $x$ & & $\begin{array}{l}\text { Identifies the allowable release limits of } \\
\text { hazardous and radioactive } \\
\text { constituents. }\end{array}$ \\
\hline
\end{tabular}




\begin{tabular}{|c|c|c|c|c|c|c|}
\hline Agency & Regulation, Standard, or Permit & $\mathrm{HA}$ & HL & RA & RL & Summary/Application \\
\hline \multirow[t]{2}{*}{$\begin{array}{l}\text { American } \\
\text { National } \\
\text { Standards } \\
\text { institute, (ANSI) }\end{array}$} & $\begin{array}{l}\text { N } 13.1^{*} \text { (ANSI 1969) } \\
\text { Guidance to Sampling Airborne } \\
\text { Radioactive Materials in Nuclear } \\
\text { Facilities }\end{array}$ & & & $x$ & & $\begin{array}{l}\text { Sets standards for effluent monitoring } \\
\text { systems }\end{array}$ \\
\hline & $\begin{array}{l}\text { ANSI N 42.18* Specification and } \\
\text { Performance of On-site } \\
\text { Instrumentation for Continuously } \\
\text { Monitoring Radioactivity in Effluents }\end{array}$ & & & $x$ & $x$ & $\begin{array}{l}\text { Recommendations for the selection of } \\
\text { instrumentation for the monitoring of } \\
\text { radioactive effluents }\end{array}$ \\
\hline \multirow{7}{*}{$\begin{array}{l}\text { Washington } \\
\text { State } \\
\text { Department of } \\
\text { Ecology, } \\
\text { Olympia WA }\end{array}$} & $\begin{array}{l}\text { WAC } 173-216 \\
\text { State Waste Discharge Permit } \\
\text { Program }\end{array}$ & & $x$ & & $x$ & $\begin{array}{l}\text { Governs discharges to ground and } \\
\text { surface waters }\end{array}$ \\
\hline & $\begin{array}{l}\text { WAC 173-220 } \\
\text { National Pollutant Discharge } \\
\text { Elimination system Permit }\end{array}$ & & $x$ & & $x$ & $\begin{array}{l}\text { Governs wastewater discharges to } \\
\text { navigable waterways; controls NPDES } \\
\text { permit process }\end{array}$ \\
\hline & $\begin{array}{l}\text { WAC } 173-303 \\
\text { Dangerous Waste Regulations }\end{array}$ & & $x$ & & & $\begin{array}{l}\text { Regulates dangerous wastes; prohibits } \\
\text { direct release to soil columns }\end{array}$ \\
\hline & $\begin{array}{l}\text { WAC } 173-400 \\
\text { General Regulations for Air Pollution } \\
\text { Sources }\end{array}$ & $x$ & & & & $\begin{array}{l}\text { Sets emissions standards for } \\
\text { hazardous air pollutants }\end{array}$ \\
\hline & $\begin{array}{l}\text { WAC } 173-401 \\
\text { Air Operating Permit Program }\end{array}$ & $x$ & & $x$ & & $\begin{array}{l}\text { Establishes an operating permit for } \\
\text { hazardous (regulated) air pollutants, } \\
\text { including radionuclides }\end{array}$ \\
\hline & $\begin{array}{l}\text { WAC } 173-460 \\
\text { Control for New Sources of Toxic Air } \\
\text { Pollutants }\end{array}$ & $x$ & & & & $\begin{array}{l}\text { Sets standards or new sources of toxic } \\
\text { air pollutants }\end{array}$ \\
\hline & $\begin{array}{l}\text { WAC } 173-480 \\
\text { Washington State Ambient Air Quality } \\
\text { Standard and Emission Limits for } \\
\text { Radionuclides }\end{array}$ & & & $x$ & & $\begin{array}{l}\text { Endorses the } 10 \mathrm{mrem} / \mathrm{year} \text { EDE-EPA } \\
\text { standards (40 CFR } 61 \text {, Subpart H) }\end{array}$ \\
\hline \multirow{3}{*}{$\begin{array}{l}\text { Washington } \\
\text { State } \\
\text { Department of } \\
\text { Health, } \\
\text { Olympia, } \\
\text { Washington }\end{array}$} & $\begin{array}{l}\text { WAC 246-247 } \\
\text { Radiation Protection - Air Emissions }\end{array}$ & & & $x$ & & $\begin{array}{l}\text { Sets standards for registration, } \\
\text { permitting, notification, new sources, } \\
\text { review, monitoring, and reports. }\end{array}$ \\
\hline & $\begin{array}{l}\text { Notice of Construction } \\
(\mathrm{DOH})\end{array}$ & & & $x$ & & If applicable \\
\hline & $\begin{array}{l}\text { FF-01 Radioactive Airborne Emissions } \\
\text { (DOH 1993c) }\end{array}$ & & & $x$ & & $\begin{array}{l}\text { Collective emissions from registered } \\
\text { sources shall meet the emissions } \\
\text { requirements of WAC } 173-480\end{array}$ \\
\hline
\end{tabular}


HNF-4200, Rev. 0

\begin{tabular}{|l|l|c|c|c|c|c|}
\hline \multicolumn{1}{|c|}{ Agency } & Regulation, Standard, or Permit & HA & HL & RA & RL & \multicolumn{1}{|c|}{ Summary/Application } \\
\hline $\begin{array}{l}\text { Benton Clean } \\
\text { Air Authority, } \\
\text { (BCAA) }\end{array}$ & Regulation 1 & $X$ & & & & $\begin{array}{l}\text { Regulates air quality regarding } \\
\text { compliance with 40 CFR 61, Subpart } \\
\text { Richland, } \\
\text { Washington }\end{array}$ \\
\hline
\end{tabular}

$H A=$ hazardous airborne.

$\mathrm{HL}=$ hazardous liquid.

$\mathrm{RL}=$ radioactive liquid.

$\mathrm{RA}=$ radioactive airborne.

*Referenced in DOE and EPA regulations. 
To determine whether a release point is subject to emission measurement requirements, it is necessary to evaluate the potential for radionuclide emissions for that release point. In evaluating the potential of a release point to discharge radionuclides into the air, the estimated radionuclide release rates shall be based on the discharge of the effluent stream that would result if all pollution control equipment did not exist, but the facility operations were otherwise normal.

Subpart $\mathrm{H}$ also states that major stacks shall be directly monitored continuously with an in-line detector or representative samples of the effluent stream shall be withdrawn continuously from the sampling site following the guidance presented in American National Standards Institute (ANSI) N13.1 (ANSI 1969). The EPA has also approved an Alternate Method for sampling using single point sampling with a shrouded probe. The requirements for continuous sampling are applicable to batch processes when the unit is in operation. Periodic sampling (grab samples) may be used only with EPA's prior approval. Such approval may be granted in cases where continuous sampling is not practical and radionuclide emission rates are relatively constant. In such cases, grab samples shall be collected with sufficient frequency to provide a representative sample of the emissions.

\subsubsection{State Operating Permit Program ( 40 CFR 70)}

This regulation defines the minimum elements required by the Federal Water Pollution Control Act of 1972 for state operating permit programs and corresponding standards and procedures by which the administrator will approve, oversee, and withdraw approval of state operating permit programs.

\subsubsection{Identification and Listing of Hazardous Waste (40 CFR 261)}

This part identified those solid wastes that are subject to regulation as hazardous waste.

\subsubsection{Designation, Reportable Quantities, and Notification (40 CFR 302)}

The regulations in "EPA Designation, Reportable Quantities, and Notification Requirements for Hazardous Substances Under CERCLA" (40 CFR 302) designate hazardous substances and identify reportable quantities and notification requirements for release of these hazardous substances under the Comprehensive Environmental Response, Compensation, and Liability Act of 1980 (CERCLA) and the Safe Drinking Water Act of 1974, as amended.

Any unpermitted release of any of these designated hazardous substances must be reported. Therefore, if the possibility exists for a facility to release any of the designated substances, waste streams must be monitored for their presence and monitoring practices must be provided in a FEMP. 


\subsection{INDUSTRY STANDARDS UNDER AMERICAN NATIONAL STANDARDS INSTITUTE}

\subsubsection{Guide to Sampling Airborne Radioactive Materials in Nuclear Facilities (ANSI N13.1-1969)}

Note: This standard is currently under revision. When issued, it will recommend performance based sampling that would allow the use of single-point sampling, i.e., a shrouded probe.

The primary objective for sampling airborne radioactivity in effluents is to measure the release of radioactive materials to the environment. This is accomplished through sampling near the point of release. The objective of ANSI N13.1 (ANSI 1969) is to set forth the principles that apply in obtaining valid samples of airborne radioactive materials and to prescribe acceptable methods and materials for gaseous and particulate sampling.

ANSI N13.1 (ANSI 1969) is limited to the collection of samples and does not address measurement of the radioactive materials collected. The exclusion of radiochemical measurement from the scope must not be construed to mean that the measurement of samples is of lesser importance than sampling.

\subsubsection{Specification and Performance of Onsite Instrumentation for Continuously Monitoring Radioactivity in Effluents (ANSI N42.18-1980)}

The objective of continuously monitoring instrumentation is to measure the quantity, and/or the rate of release of radionuclides in the effluent stream and to provide useful documentation for scientific and logical purposes. This standard applies to continuous monitors that measure normal releases, detect inadvertent releases, show general trends, and annunciate radiation levels that have exceeded predetermined values. This standard specifies detection capabilities, physical operating limits, reliability, and calibration requirements and sets forth minimum performance requirements for effluent monitoring.

\subsection{WASHINGTON STATE REGULATIONS}

\subsubsection{Air Operating Permit Program (WAC 173-401}

The provisions in this regulation establish the element of a comprehensive Washington State air operating permit program consistent with the requirements of the Federal Clean Air Act of 1977. All sources (hazardous and radionuclides pollutants) subject to this regulation shall have a permit to operate that assures compliance by the service with all applicable requirements. 


\subsubsection{Ambient Air Quality Standards and Emission Limits For Radionuclides (WAC 173-480)}

Although the standard for Washington State establishes a 25-mrem/year (cumulative) dose limit for public exposure to radionuclide emissions, facilities must comply with the more current and more restrictive of federal, state or local law. Therefore, the exposure limit that must be complied with is $10 \mathrm{mrem} / \mathrm{year}$ (effective dose equivalent) for the air pathway. Compliance is calculated for the nearest offsite receptor in an unrestricted area where any member of the public may be located.

\subsubsection{Radiation Protection - Air Emissions (WAC 246-247)}

This regulation specifies new source review, notification, registration, and permitting requirements associated with any source of radioactive air emissions in Washington State, including those on the Hanford Site. One requirement listed in WAC 246-247 is the semiannual reporting of emissions from each registered stack or vent onsite. By agreement with Washington State Department of Health, only annual reporting is required.

\subsubsection{Water Quality Standards for Groundwater (WAC 173-200)}

The water quality standards to protect groundwater to the level of drinking water standards are contained in "Water Quality Standards for Groundwater of the State of Washington (WAC 173-200). These standards limit exposure to gross alpha, gross beta, tritium, ${ }^{90} \mathrm{Sr}$, and $226,228 \mathrm{Ra}$. For radionuclides that are not specifically listed, exposures are limited by the federal standard to an EDE not to exceed $4 \mathrm{mrem} / \mathrm{year}$.

\subsubsection{State Waste Discharge Permit Program (WAC 173-216)}

The purpose of this state regulation is to implement a state permit program, applicable to the discharge of waste materials from industrial operations into ground and surface waters of the state. However, this regulation excludes point service discharge of pollutants into navigable waters of the state, which is regulated by the "National Pollutant Discharge Elimination System Permit Program" (WAC 173-220). This regulation also excludes the injection of fluid through wells, which is regulated by "Underground Injection Control Program" (WAC 173-218).

\subsubsection{Dangerous Waste Regulations (WAC 173-303)}

Any release of a dangerous or hazardous substance (as designated by the Washington [State] Administration Code) to the environment, except permitted releases, must be reported. Waste streams that have the potential to contain dangerous waste constituents must be monitored accordingly. 
HNF-4200, Rev. 0

\section{$3.5 \quad$ LOCAL REGULATIONS}

\subsubsection{Benton County Air Authority (BCAA)}

The local air pollution control authority has jurisdiction over open burning and asbestos handling in Benton County areas, including the Hanford Site. Currently, there are no local standards more restrictive than the previously mentioned state and federal limits; therefore state and federal standards apply.

\subsection{AIR EMISSIONS}

DOE Order 5400.5 provides requirements for the monitoring of radioactive and nonradioactive airborne effluents from DOE facilities at the Hanford Site. This order states that DOE-controlled facilities must comply with NESHAPs (40 CFR 61, Subpart H).

Additional EPA requirements on hazardous substances are contained in the Comprehensive Environmental Response, Compensation and Liability Act of 1980 (CERCLA). This regulation provides information on reportable quantities of nonradioactive hazardous substances. Unlisted hazardous substances designated by CERCLA are regulated in accordance with the EPA toxicity of the contaminant.

In Washington State, airborne effluents are regulated by the Washington State Department of Ecology through regulations in the WAC, Title 173, Chapters 173-400 through 173-480, as amended, pursuant to the Washington Clean Air Act of 1967 (RAW 70.94, as amended). General regulations for air pollution sources are presented in WAC 173-400, including emission standards for sources emitting hazardous air pollutants found in WAC 173-400-075.

WAC 246-247, Radiation Protection - Air Emissions, specifies new source review, notification, registration, and permitting requirements associated with any source of radioactive air emissions in Washington State, including those on the Hanford Site. By agreement with the Washington State Department of Health, only annual reporting is required.

WAC 173-480, Ambient Radionuclides, defines maximum allowable levels for radionuclides in the ambient air and defines required levels for control of emissions. WAC 173-480 lists an outdated dose standard of $25 \mathrm{mrem} / \mathrm{yr}$. However, it contains a caveat stating that more stringent federal standards take precedence, therefore endorsing the 10 mrem/year EDE standard of NESHAP ( 40 CFR 61), Subpart $H$.

Regulations, including DOE Orders, state that DOE facilities must comply with the requirements set forth in NESHAP (40 CFR 61). Other regulations (e.g., 40 CFR 52, "Approval and Promulgation of Implementation Plans"; and DOE Orders 5400.1 (DOE 1988a), 5400.5 (DOE 1990a), DOE/EH-0173T (DOE 1991b), and 5484.1 (DOE 1981) state that DOE facilities must comply with the applicable requirements set forth in the Washington Clean Air Act of 1967. 
HNF-4200, Rev. 0

\section{$3.7 \quad$ LIQUID EFFLUENTS}

Depending on where a liquid effluent (wastewater) is discharged, certain regulations apply. These regulations are implemented through issuance of permits by federal, state, and/or local agencies. It is the responsibility of the facility, through the Richland Operations Office (RL), to apply for the permit appropriate to the effluent being discharged. Before applying for any permits, the applicant must know the source of wastewater discharges and where the wastewater is being discharged.

Each type of discharge permit identified will typically contain discharge limitations and monitoring requirements. However, the limitations and monitoring requirements will vary depending on the source and type of wastewater being discharged. Washington State controls discharges to ground water and surface water of the state, under WAC-173-216, State Waste Discharge Permit Program, and issues permits for such discharges. 
HNF-4200, Rev. 0

\subsection{IDENTIFICATION AND CHARACTERIZATION OF EFFLUENT STREAMS}

This section provides information on the identification and characterization of effluent streams for normal and upset conditions.

\subsection{IDENTIFICATION AND CHARACTERIZATION OF SOURCE TERMS CONTRIBUTING TO EACH EFFLUENT STREAM}

\subsubsection{Liquid Effluents} following.

Identification and characterization of contributors to each liquid effluent stream is presented in the

\subsubsection{WESF Liquid Effluent (WLE)}

The major contributor to this stream is cooling water for the air compressors in $225-\mathrm{BC}$. This system can also receive contributions from heating, ventilation, and air conditioning condensate, steam condensate, and storm water runoff from three street drains and two yard drains.

Potential contributors to the WLE stream include the WESF steam condensate (primarily from the HVAC room and reducing station on the north wall of 225-B). Administrative controls are, however, in place to preclude the introduction of these areas into the WLE stream. The WLE discharges to TEDF via TEDF pump station \#2.

\subsubsection{Sanitary Sewers}

A new sanitary sewer system is installed in the 200 East area. Sanitary sewage effluent from WESF is routed to a pressurized sewer pump station located north of the $221 \mathrm{~B}$ building and Atlanta Avenue. Liquid sewage will then be routed to the 200 East drain fields located near Baltimore Avenue.

\subsubsection{WCW}

Contributors to the WCW are the WESF pool cell closed loop cooling system and raw water used as single pass cooling water from the WESF pool cell heat exchangers. Discharge of the single pass cooling water from the WESF pool cell heat exchangers would occur should the closed loop cooling system fail. An additional source to this stream is the monthly test of the backup well water supply system.

All water discharged from the Closed Loop Cooling System is routed to a sump in Building 225-BG. When the level in the sump reaches a pre-determined value, the lead sump pump will start and pump the water level to a low setpoint. The discharge line is checked for flow, temperature, conductivity and $\mathrm{pH}$. 
HNF-4200, Rev. 0

This information is available locally, at the WPMCS in WESF, and at TEDF. The water discharges into a pipeline going to TEDF. This line is sampled bi-monthly.

\subsubsection{Air Effluents}

This section provides information on the identification and characterization of contributors to each air effluent stream.

\subsubsection{WESF Stack}

Information on the WESF stack contributors is as follows.

The 296-B-10 Stack--The 296-B-10 Stack handles the exhaust of filtered air effluent released from WESF to the atmosphere. The stack exhausts to the atmosphere air effluents from the 225-B Building ventilation systems K-1, K-3, and K-4. The WESF main stack handles a flowrate of approximately $18,000-20,000$ $\mathrm{ft}^{3} / \mathrm{min}$.

\subsection{ROUTINE OPERATING CONDITIONS}

\subsubsection{Liquid Effluents}

Information about the identification and characterization of contributors to each liquid effluent stream during normal operating conditions is presented in the following.

\subsubsection{WLE}

The WLE handles water flushes, steam condensate, and other liquid streams that do not contain radioactive or chemical contaminants. Water is the only constituent in the WLE stream. This appears to be in contrast to the constituents listed in Table 8-1. It should be noted that the data for table 8-1 was collected from the same line used to discharge the B Plant chemicals and some residual contamination remains in the line. Raw water, cooling, water, steam condensate, and sanitary water are the current constituents to the WLE.

\subsubsection{WCW}

The WCW consists of cooling water blowdown, periodic backup well testing, and potentially, raw water used as discharge single pass cooling water from the WESF pool cell heat exchangers. Discharge of single pass cooling water from the WESF pool cell heat exchangers will occur should the closed loop cooling system fail. Biocide chemicals are added to the closed loop cooling water and are the only chemical constituent to the WCW stream. 
Engineered features are in place to preclude the discharge of radiological contaminants. Waste streams are monitored for water treatment chemicals to control discharge within interface control limits as shown in Table 8-2. Potential water treatment chemical spills are controlled in a containment sump.

\subsubsection{Air Effluents}

Historical monitoring data from the WESF stack and vents consist mainly of gross alpha and beta results. Estimates of individual radionuclides released from the WESF stack under routine operating conditions are given in Table 4-1. Maximum measured gross alpha and gross beta values for the stack during the 1985-1995 time period found in Table 8-4 was used to estimate the individual radionuclide emissions given in Table 4-1. Activity percentages for the individual radionuclides, as given in Footnote $B$

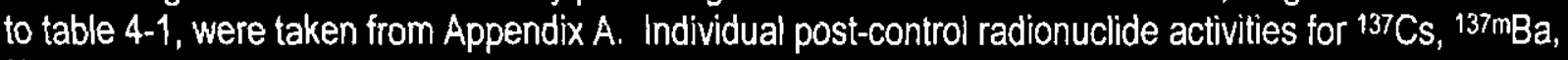
${ }^{90} \mathrm{Sr}$, and ${ }^{90} \mathrm{Y}$ were calculated by multiplying the measured post-control beta activity by the activity percentage for the individual beta/gamma emitters.

Likewise, post-control alpha emitter concentrations were calculated by multiplying the measured post-control alpha activity by the activity percentages for the individual alpha emitters. The stack release values given in Table 4-2 represent the calculated post-control radionuclide concentrations (Table 4-1). The offsite post-control values given in Table 4-2 were calculated by multiplying the stack release values by the atmospheric dispersion factor $(X / Q)$ of $1 \mathrm{E}-05$, which was taken from the $B$ Plant Preliminary Accident Analysis (WHC 1989c). The regulatory limits for each radionuclide given in Table 4-2 are based on the NESHAPs standard of $10 \mathrm{mrem} / \mathrm{yr} \mathrm{EDE}$, assuming the radionuclide in question is the only one released and that the stack in question is the only release point for the facility. The offsite post-control percent regulatory limit was calculated by dividing the offsite post-control value by the regulatory limit. The offsite percent regulatory pre-control limit was calculated by multiplying the offsite post-control percent regulatory limit by the DF. The potential to emit for the 296-B-10 stack is .13Ci/yr unabated (NOC-K-3 duct characterization 2/26/98).

The DFs in Table 4-2 were determined based on WHC-EP-0498 (WHC 1991d). The offsite precontrol percent regulatory limit was determined because when determining whether effluent monitoring is required, emission controls between the point of generation and the discharge point are not to be considered. 
Table 4-1 Maximum Annual Average Calculated Radionuclide-Specific Stack Releases for Routine Operations.

\begin{tabular}{|c|c|c|c|c|c|c|c|c|c|}
\hline \multirow[b]{2}{*}{ Stack } & \multicolumn{2}{|c|}{$\begin{array}{c}\text { Post-control concentration }^{\mathrm{a}} \\
(\mu \mathrm{Ci} / \mathrm{mL}) \\
\end{array}$} & \multicolumn{6}{|c|}{$\begin{array}{l}\text { Calculated post-control radionuclide concentrations }{ }^{b} \\
(\mu \mathrm{Ci} / \mathrm{mL})\end{array}$} & \multirow[b]{2}{*}{ DF } \\
\hline & Beta & Alpha & ${ }^{137} \mathrm{Cs}$ & ${ }^{137} \mathrm{Ba}$ & $90 \mathrm{Sr}$ & $90 Y$ & $239,240 \mathrm{Pu}$ & ${ }^{241} \mathrm{Am}$ & \\
\hline $296-B-10$ & 8.12 E-13 & $<3.52$ E-15 & 2.44 E-13 & 2.44 E-13 & 1.62 E-13 & $1.62 \mathrm{E}-13$ & $<2.71$ E-15 & $<8.10 \mathrm{E}-16$ & $\begin{array}{l}3 \mathrm{E}+03^{c} \\
3 \mathrm{E}+03^{c}\end{array}$ \\
\hline
\end{tabular}

a Maximum value for years 1985-1995; taken from Table 8.4 .

bEmissions calculated from beta and alpha concentrations based on $30 \% \mathrm{Cs}, 30 \% \mathrm{Ba}, 20 \% \mathrm{Sr}$, and $20 \%$ Y for betalgamma emitter and $77 \%$ Pu and $23 \%$ Am for alpha emitters. Source: Appendix A.

cWHC-EP-0498 Unit Dose Calculation Methods and Summary of Facility Effluent Plan Determinations

(WHC 1991C)

Table 4-2 Comparison of Routine Stack Releases With Regulatory Limits for the 296-B-10 Stack.

\begin{tabular}{|c|c|c|c|c|c|}
\hline \multirow[b]{2}{*}{ Constituent } & \multicolumn{2}{|c|}{ Post-Control concentration $(\mu \mathrm{Ci} / \mathrm{mL})$} & \multirow{2}{*}{$\begin{array}{l}\text { Regulatory limitc } \\
\qquad(\mu \mathrm{Ci} / \mathrm{mL})\end{array}$} & \multicolumn{2}{|c|}{ Offsite \% regulatory limit } \\
\hline & Stack release ${ }^{a}$ & Offsiteb $^{b}$ & & Post-control & Pre-controld \\
\hline${ }^{137} \mathrm{Cs}$ & $2.44 E-13$ & $2.44 E-18$ & $4.0 \mathrm{E}-10$ & 6.10 E-07 & $1.83 \mathrm{E}-03$ \\
\hline $137 \mathrm{mBa}$ & $2.44 E-13$ & $2.44 E-18$ & $3.0 \mathrm{E}-08$ & $8.13 \mathrm{E}-10$ & 2.44 E-05 \\
\hline${ }^{90} \mathrm{Sr}$ & $1.62 \mathrm{E}-13$ & $1.62 E-18$ & $9.0 \mathrm{E}-12$ & $1.80 \mathrm{E}-05$ & $5.40 \mathrm{E}-02$ \\
\hline $90 Y$ & $1.62 \mathrm{E}-13$ & $1.62 \mathrm{E}-18$ & 1.0 E-09 & 1.62 E-07 & 4.86 E-04 \\
\hline $239,240 \mathrm{Pu}$ & $<2.71 \mathrm{E}-15$ & $<2.71 \mathrm{E}-20$ & $2.0 E-14$ & $<1,36 \mathrm{E}-04$ & $<4.08 \mathrm{E}-01$ \\
\hline${ }^{241} \mathrm{Am}$ & $<8.10 \mathrm{E}-16$ & $<8.10 \mathrm{E}-21$ & $2.0 \mathrm{E}-14$ & $<4.05 \mathrm{E}-05$ & $<1.22$ E.01 \\
\hline & & & & Total & $<5.86$ E -01 \\
\hline
\end{tabular}

aFrom Table 4-1.

bCalculated based on an atmospheric dispersion factor (XVQ) of 1 E-05 for the offsite maximally exposed individual.

'Based on the NESHAPs (EPA 1991a) standard of $10 \mathrm{mrem} / \mathrm{yr}$ EDE and assuming that the radionuclide in question is the only one released and that the stack is the only release point for the facility.

${ }^{d}$ Calculated by multiplying the post-control offsite percent regulatory limit by the DF (see Table 4-1). Any radionuclide contributing at least $10 \%$ of the dose from the stack must be measured.

The following subsection provides information on the identification and characterization of contributors to each air effluent stream during normal operating conditions.

\subsubsection{WESF Stacks}

Information on WESF stack contributors during normal conditions is as follows.

The 296-B-10 Stack--During normal process operations, the ventilation systems maintain segregation of contaminated areas in WESF. Radioactive contamination spread during normal operation occurs predominantly from manipulator replacements. Loose contamination on the manipulator can drop to the operating gallery floor during replacement or become airborne and spread to other surfaces, as well as to the K-1 HVAC system. 
The K-1 Heating, Ventilation, and Air Conditioning Supply and Exhaust System--The areas ventilated with the K-1 system vary in contamination potential from very low to areas that are moderately contaminated. Of these areas, regulated manipulator repair represents the highest potential for contamination, resulting from contaminated manipulator repair and decontamination. The major isotopes involved are ${ }^{137} \mathrm{Cs}$ and ${ }^{90 \mathrm{Sr}}$.

The K-3 Heating, Ventilation, and Air Conditioning Supply and Exhaust System--The canyon and process cells, which are supplied and exhausted by the K-3 HVAC System, are normally the most contaminated areas of WESF. Up to $1 \mathrm{MCi}$ of cesium and $1 \mathrm{MCi}$ of strontium legacy contamination could be available within the process cells of the WESF.

The K-4 Heating, Ventilation, and Air Conditioning Supply--The K-4 HVAC system supplies air to the capsule storage area on a once-through basis. Although a large inventory of cesium and strontium are stored in the pool cells, the material is double encapsulated and stored in pool cells with approximately 13 feet of water; therefore, they are not considered a credible source term. The pool cell area is free of smearable contamination.

\subsection{UPSET OPERATING CONDITIONS}

\subsubsection{Liquid Effluents}

Information on identifying and characterizing the contributors to each liquid effluent stream during upset operating conditions is provided in the following. The two liquid effluent streams discharge to TEDF and there is no potential for release to the environment during upset conditions.

\subsubsection{WLE}

Administrative controls are in place to prevent the discharge of radiological or chemical contaminants into the WLE system.

\subsubsection{WCW}

Chemicals such as citric acid, and water treatment chemicals such as biocide and corrosion inhibitors are stored in the chemical addition room in 225-BG. There is potential for over-addition of chemicals to the stream, however, administrative and engineered controls are in place to prevent excess chemical addition. Appropriate monitoring and sampling systems are in place to detect discharges above established limits. 


\subsubsection{Air Effluents}

The following subsection provides information on the identification and characterization of contributors to each air effluent stream during upset operating conditions. Estimate of radioactivity releases have been made, and these are discussed in the appropriate section of the referenced documents.

\subsubsection{WESF Stacks}

Information on WESF stack contributors during upset operating conditions is as follows.

The 296-B-10 Stack--Abnormal spreads of contamination can occur if there is a loss of, or reversal of, differential pressure. Engineering controls such as automatic shutdown, interlocks, and alarms are incorporated to reduce chances of occurrence.

If a ventilation failure occurs, the backup exhaust fans are designed to turn on automatically. If any one system fails, safety interlocks are built into the HVAC systems to prevent a total loss of air flow and differential pressure.

The K-1 Heating, Ventilation, and Air Conditioning Supply and Exhaust System--Areas that are exhausted by the K1 system, and have a high potential for radioactive contamination, are equipped with HEPA filters as pre-filters. These areas include the Manipulator Hot Shop and the transmitter rooms.

The K-3 Heating, Ventilation, and Air Conditioning Supply and Exhaust System--The process hot cells contain the largest potential radioactive inventory and each cell contains HEPA filters as pre-filters to the K3 exhaust.

With the containment and confinement features provided by the process cell design, as well as the filtration/ventilation system, no major incidents of contamination release to the environment have been experienced from K-3 Process Cell operations.

The K-4 Heating, Ventilation and Air Conditioning Supply--Since the capsules are maintained under 13 feet of water and the water is monitored for radioactivity content, the potential for airborne release from this source is low.

\subsubsection{Upset Scenarios.}

Accident scenarios have been analyzed for various gaseous upset conditions in the WESF Safety Analysis Report (1996). A description of the scenario, releases, and resulting exposures can be found in the referenced document. All assumptions made in these scenarios are made in order to present a "worst case" accident. Therefore, all estimated onsite and offsite doses consequences are conservatively high estimates. 


\subsection{EFFLUENT POINT OF DISCHARGE DESCRIPTION}

As used herein, effluent discharge points are defined as the final point where effluents are monitored, sampled, diverted, otherwise controlled, or where the stream exits the facility into the environment.

The following describes the liquid and gaseous effluent points at WESF.

\section{$5.1 \quad$ LIQUID EFFLUENTS}

Liquid effluent discharge points are presented in Table 5-1.

Table 5-1 Liquid Effluent Discharge Points

\begin{tabular}{|l|l|l|l|}
\hline $\begin{array}{l}\text { Hanford Site effluent point } \\
\text { designation }\end{array}$ & \multicolumn{1}{|c|}{ Associated facility } & \multicolumn{1}{c|}{$\begin{array}{c}\text { Identification of } \\
\text { contributing streams }\end{array}$} & $\begin{array}{l}\text { Physical dimensions of } \\
\text { effluent point } \\
\text { 151 Monitoring Station }\end{array}$ \\
WESF 225 -BG Sump & $225 B$ & WCW & 3 " pipe \\
& & & 1,000 gallon working \\
& & & \\
\hline
\end{tabular}

\subsubsection{The WESF Liquid Efiluent to TEDF via F-Line}

The contributors discharging to the WLE stream include cooling water from air compressors in the 225-BC Building, steam condensate, 225-B, and pool cell 9 and 10. This stream discharges to a pipe-line going to TEDF (F-line) at approximately 5-10 gal/min.

\subsubsection{WESF Cooling Water (WCW)}

The contributors discharging to the WCW are the WESF pool cell closed loop cooling system, raw water used as discharge single pass cooling water from the WESF pool cell heat exchangers, and the monthly test of the backup well water supply system. The water then discharges to a pipe-line going to TEDF (E-Line) with a continuous flow rate of approximately $100 \mathrm{gal} / \mathrm{min}$. 
HNF-4200, Rev. 0

\subsection{AIR EFFLUENTS}

Air effluent discharge points are shown in Table 5-2 and are discussed below.

\subsubsection{The Waste Encapsulation Storage Facility Stack}

\subsubsection{The 296-B-5 Stack}

The 296-B-5 stack was closed per Letter FDH-975573.1.

\subsubsection{The 296-B-10 Stack}

This stack exhausts filtered air from the WESF at a rate of $20000 \mathrm{ft}^{3} / \mathrm{min}$.

Table 5-2 Air Effluent Discharge Points

\begin{tabular}{|l|c|c|}
\hline $\begin{array}{c}\text { Hanford Site effluent point } \\
\text { designation }\end{array}$ & $\begin{array}{c}\text { Associated facility and identification of contributing } \\
\text { streams }\end{array}$ & Physical dimensions of discharge point \\
\hline 296-B-10 Stack & $\begin{array}{l}\text { 225-B WESF main stack } \\
\text { Height, } 21.3 \mathrm{~m}(70 \mathrm{ft}) \text {; dia., } \\
10.7 \mathrm{~m}(42 \mathrm{in})\end{array}$ \\
\hline
\end{tabular}

\subsubsection{The 296-B-13 Stack}

The 296-B-13 stack was closed per letter FDH-9754089.1.

\subsubsection{Waste Encapsulation Storage Facility Emergency Jet (296-B-12)}

The WESF emergency jet is closed. 
HNF-4200, Rev. 0

\subsection{EFFLUENT MONITORINGISAMPLING SYSTEM DESIGN CRITERIA}

DOE Order 5400.1 states that "effluent monitoring shall comply with applicable regulations and shall be conducted to provide representative measurements of the quantities and concentrations of contaminants in liquid and airbome discharges and solid wastes" (DOE 1991c). This section addresses the monitoring/sampling equipment design criteria and the basis used to establish sampling intervals for effluent streams.

\subsection{LIQUID EFFLUENT DESIGN CRITERIA}

Design criteria for WESF liquid effluents is presented as follows:

\subsubsection{WESF Cooling Water (WCW)}

A Closed Loop Cooling System (CLCS) was installed early in 1997 for the pool cell heat exchanger cooling water to augment the once-through raw water cooling system currently in place. The CLCS system provides the primary source of cooling water to the pool cell heat exchangers so that the functional requirements related to cooling the pool cell water can still be met for fully loaded pool cells. With the CLCS in operation, the liquid effluent discharge rate associated with the cooling system decreased from over $3,785 \mathrm{~L} / \mathrm{min}(1,000 \mathrm{gal} / \mathrm{min})$ to approximately $114 \mathrm{~L} / \mathrm{min}(30 \mathrm{gal} / \mathrm{min})$. Liquid effluent is routed to the Treatment Effluent Disposal Facility (TEDF) rather than being discharged to $B$ Pond as in the past.

A local control unit building (225-BG) houses the new motor control center, the closed loop circulation pumps, a programmable logic controller (PLC), a fluid cooler chemical addition system, and a cooling water effluent stream sump. All water discharged from the WCW system is routed to the sump in 225-BG building. When the level in the sump reaches a pre-determined value, the lead sump pump will start and pump the water level to a low setpoint. The discharge line is checked for flow, temperature, conductivity and $\mathrm{pH}$. This information is available locally, at the WPMCS in WESF, and at TEDF. The water discharges into a pipeline going to TEDF. This discharge is sampled bi-monthly in accordance with the TEDF ICD agreement.

\subsubsection{WLE}

A monitoring system is installed in the 151 monitoring station to provide flow and $\mathrm{pH}$ monitoring for the WLE discharge stream. Signals from the flow and pH monitors are received and monitored in the WESF Process Monitoring and Control System (WPMCS). The $\mathrm{pH}$ analyzer has a detection range of 0 to $14 \mathrm{pH}$, a low alarm setting of $6.5 \mathrm{pH}$, and a high alarm setting of $8.0 \mathrm{pH}$.

Sampling of the WLE stream is performed at the 151-BA monitoring station. This location is downstream from all contributors. The WLE stream is sampled in accordance with the TEDF ICD. 
HNF-4200, Rev. 0

\subsection{Air Effluent Design Criteria}

Design criteria for WESF air effluents is presented in the following. All CAMs utilized in the stacks are Eberline AMS-3 monitors. They have a rated efficiency of 50 percent for ${ }^{90} \mathrm{Sr} / 90 \mathrm{Y}$ and a count rate range of 10 to $100,000 \mathrm{cpm}$. Gamma response is approximately $200 \mathrm{cpm} / \mathrm{mR} / \mathrm{h}$ of ${ }^{60} \mathrm{Co}$. All filter particulate samples are collected on $47 \mathrm{~mm}$ filter paper at a flowrate of $2.0 \pm 0.2 \mathrm{ft}^{3} / \mathrm{min}$. Samples are analyzed at an established frequency and are measured by analytical methods.

\subsubsection{The 296-8-10 System}

Radionuclides are the primary emissions of concern from the WESF 296-B-10 Stack.

The sampling and monitoring system for the 296-B-10 Stack is based on a design developed for site-wide application to airbome effluents associated with 200 Area facilities. A flow rate element, installed in the main stack airstream, measures the air flow. An electrical signal, proportional to the stack flow, is transmitted to instruments in the supervisory panel in the WESF operating gallery. Isokinetic air extraction probes are positioned in the stack. The probes are installed to withdraw air from the stack into the record sampler. 
HNF-4200, Rev. 0

\subsection{CHARACTERIZATION OF THE CURRENT EFFLUENT MONITORING SYSTEM}

This section describes the effluent monitoring system (EMS) and technical specifications related to the effluent monitoring/sampling systems.

\subsection{INSTRUMENTATION DESCRIPTION}

The ability to detect, quantify, and adequately respond to unplanned releases of radioactive material from WESF to the environment relies upon in-place effluent sampling and monitoring systems. These sampling/monitoring systems are based on designs developed for site-wide application to effluents associated with the 200 Area facilities to determine whether effluent releases of radioactive material are within the DCGs specified in DOE Order 5400.5 (DOE 1990b). Tables 7-1 through 7-4 list the instrumentation, operating ranges, alarm setpoints, and comparative regulatory limits.

Each sampling/monitoring system allows for the collection of a record (historical) and a process control sample. The WESF stack ties to the panels in the WESF operating gallery and operating base. WESF Plant Monitoring and Control System (WPMCS) monitors liquid effluent for E-Line and F-Line.

Calibration, maintenance, and testing procedures for the monitoring, diversion, and sampling systems are prepared in accordance with Hanford site standards. The WLE flowmeter is calibrated every 6 months. The WCW and the 296-B019 stack flowmeters are calibrated yearly. All units are recalibrated when maintenance or modifications may affect equipment performance. Sampling and monitoring systems are routinely checked with known sources to determine that they function properly.

\subsection{TECHNICAL SPECIFICATIONS PERTAINING TO EFFLUENT MONITORING SYSTEM}

\subsubsection{Liquid Effluents}

\subsubsection{WLE}

Flow proportional composite sampling of the WLE stream, in accordance with the TEDF interface control document, (ICD) WHC-SD-W049H-ICD-001, Rev. 4, is performed at the 151 monitoring station. When the flow totalizer has measured a preset volume, the sampler is activated, and a predetermined sample volume is collected. Flow proportional samples are collected over a 24-hour period once every two months as required by the TEDF ICD. 
Table 7-1 Liquid Effluent Monitoring Instrumentation WESF Liquid Effluent.

\begin{tabular}{|l|l|l|l|l|}
\hline \multicolumn{1}{|c|}{ Component } & \multicolumn{1}{c|}{$\begin{array}{c}\text { Manufacturerl } \\
\text { Model }\end{array}$} & $\begin{array}{c}\text { Specifications/operating- } \\
\text { ranges }\end{array}$ & Alarm setting & ICD limits \\
\hline \multicolumn{3}{|c|}{ Primary Environmental Monitor located in the 151 Pit } \\
\hline $\begin{array}{l}\text { pH analyzer } \\
\text { AE-TE-151-9000-1 }\end{array}$ & Rosemount/385t & $\begin{array}{l}\text { Range: } 0.14 \text {; automatic } \\
\text { temperature compensation }\end{array}$ & $\begin{array}{l}\text { Lo } 6.5 \mathrm{pH} \\
\mathrm{Hi} 8.5 \mathrm{pH}\end{array}$ & $\begin{array}{l}106.5 \mathrm{pH} \\
\mathrm{Hi} 8.5 \mathrm{pH}\end{array}$ \\
\hline $\begin{array}{l}\text { Flow Meter } \\
\text { FiT-151-9000-1 }\end{array}$ & Brooks/3585 & $0-600 \mathrm{gpm}$ & None & $\begin{array}{l}<00 \text { gpm averaged over 4 } \\
\text { hours }\end{array}$ \\
\hline \hline
\end{tabular}

Table 7.2 Liquid Effluent Monitoring Instrumentation WESF Cooling Water

\begin{tabular}{|c|c|c|c|c|}
\hline Component & $\begin{array}{l}\text { Manufactureri } \\
\text { Model }\end{array}$ & $\begin{array}{l}\text { Specifications/Oper- } \\
\text { ating ranges }\end{array}$ & Alarm Setting & Regulatory Limits \\
\hline \multicolumn{5}{|c|}{ Primary Environmental Monitor Located in 225-BG Sump } \\
\hline $\begin{array}{l}\text { Temperature } \\
\text { 225-BG-1T-9000-1 }\end{array}$ & $\begin{array}{l}\text { Foxbord } \\
\text { RTT-S15NQCD }\end{array}$ & $4-20 \mathrm{~mA}$ & $\begin{array}{l}\text { lo } 39 \mathrm{~F} \\
\text { hi } 120 \mathrm{~F}\end{array}$ & None. \\
\hline $\begin{array}{l}\text { PH } \\
\text { 225BG-AG-9000-2 }\end{array}$ & $\begin{array}{l}\text { Great Lakes/ } \\
\text { 692E3F5A7N } \\
\end{array}$ & $0-14 \mathrm{pH}$ & $\begin{array}{l}\text { Lo } 6.5 \mathrm{pH} \\
\mathrm{Hi} 8.5 \mathrm{pH} \\
\end{array}$ & $\begin{array}{l}6.5 \mathrm{ll} \\
8.5 \mathrm{hi} \\
\end{array}$ \\
\hline $\begin{array}{l}\text { Conductivity } \\
\text { 225BG-AE-9000-1 }\end{array}$ & $\begin{array}{l}\text { Great Lakes/ } \\
\text { 692E3F5AON } \\
\end{array}$ & $0-600 \mu \mathrm{S}$ & & No target limit \\
\hline $\begin{array}{l}\text { Flow meter } \\
\text { 225BG-FIT-9000-1 }\end{array}$ & $\begin{array}{l}\text { Krohne/ } \\
\text { IFS-4000-F }\end{array}$ & $0-100 \mathrm{GPM}$ & None & 105a gallmin \\
\hline
\end{tabular}


Table 7-3 Primary Record Sampler Located at the 225-B Building (B-748)

\begin{tabular}{|c|c|c|}
\hline Record filter paper holder & BGI Incorporated & $\begin{array}{l}47 \mathrm{~mm} \text { filter paper (Gelman Sciences); sample probes: } 6 \text { isokinetic } \\
\text { tubes located } 45 \mathrm{ft} \text { from base of stack }\end{array}$ \\
\hline Flow totalizer & Rockwell/MR-9 & $8.92 \mathrm{~m}^{3 / \mathrm{h}}$ at $5 \mathrm{psi}$; temperature compensated at $600 \mathrm{~F}$ \\
\hline Flowmeter & Dwyer/RMC & $\begin{array}{l}\text { Pressure rating: } 35 \mathrm{psi} \text {; temperature rating: to } 130^{\circ} \mathrm{F} \text {; accuracy: } 2 \% \\
\text { of full scale; maintained at } 2.0 \mathrm{cmm}\end{array}$ \\
\hline Flow switch & Chem-Tech/500-316-BP & $\begin{array}{l}\text { Maximum pressure: } 0.2 \mathrm{scf} / \mathrm{min} \text { to } 35 \mathrm{scf} / \mathrm{min} \text { at } 15 \mathrm{psi}, 45 \mathrm{scf} / \mathrm{min} \text { at } \\
60 \text { psi; sample probes: } 2 \text { isokinetic tubes located at } 45 \mathrm{ft} \text { from base } \\
\text { of stack }\end{array}$ \\
\hline Flow control valve & Eberline/10552-CO2-RAP-1R & \\
\hline Vacuum pump & Gast0 022 or 0823 & Oilless, - H.P. rating; capacity: $7.2 \mathrm{cfm}$ at $0^{\prime \prime} \mathrm{Hg}$ and $1,725 \mathrm{rpm}$ \\
\hline \multicolumn{3}{|c|}{ Process control sampler located at the 225-B Building (B-822). } \\
\hline Continuous air monitor & Eberline/AMS-3 Beta-Gamma & $\begin{array}{l}\text { Detector: a pancake G-M tube that is } 1-3 / 4 \text { in. in diameter with a } 1.4 \\
-2.0 \mathrm{mg} / \mathrm{cm}^{2} \text { mica window; scale: logarithmic; range: } 10-100 \mathrm{~K} \\
\mathrm{cpm} \text {; airlow meter: } 10-100 \text { Limin maintained at } 2 \mathrm{cfm} \text {; temperature } \\
\text { range: } 20^{\circ} \mathrm{F} \text { to } 120^{\circ} \mathrm{F}\left(-7^{\circ} \mathrm{C} \text { to } 49^{\circ} \mathrm{C}\right) \text {; sample probes: } 2 \text { isokinetic } \\
\text { tubes located } 45 \mathrm{ft} \text { from base of stack } \\
\text { Alarm setting: } 1,000 \mathrm{cpm}\end{array}$ \\
\hline Flow switch & Chem-Tec/500-316-BP & $\begin{array}{l}\text { Maximum pressure: } 0.2 \mathrm{scf} / \mathrm{min} \text { to } 35 \mathrm{sc} / \mathrm{min} \text { at } 15 \mathrm{psi}, 45 \mathrm{scf} / \mathrm{min} \text { at } \\
60 \mathrm{psi} \text {; sample probes: } 2 \text { isokinetic tubes located } 45 \mathrm{ft} \text { from base of } \\
\text { stack }\end{array}$ \\
\hline Flow control valve & Ebertine/10552-CO2-RAP-1R & \\
\hline Vacuum pump & Gast 0822 or 0823 & Oilless; - H.P. rating; capacity: $7.2 \mathrm{cfm}$ at $0^{\prime \prime} \mathrm{Hg}$ and $1,725 \mathrm{~mm}$ \\
\hline
\end{tabular}

\subsubsection{Sanitary Sewers}

No sampling or monitoring is performed on these systems.

\subsubsection{WCW}

All discharges from the WCW system are routed to the 225-BG sump. The sump is equipped with two discharge pumps, sampler, and associated instrumentation. The discharge flow to TEDF is monitored for $\mathrm{pH}$, conductivity, flow and temperature. Alarms are provided on the CLDCS Local Control Unit, WPMCS and TEDF Micon system. There are no automatic responses associated with these alarms.

A flow element is located on the discharge line to TEDF. The flow element provides indication of discharge flow rate and $\mathrm{pH}$ on the LCU, WPMCS and TEDF Micon system.

The sampler is an automatic composite sampler that takes the required samples of the sump effluent when aligned for automatic operation. Piping and system controls are also provided to allow manual sampling when required. The sampler operation is controlled locally with a PLC controller. 
HNF-4200, Rev. 0

\subsubsection{Air Effluents}

\subsubsection{296-B-10}

A low flow sample rate in the 296-B-10 Stack will activate a local alarm and a remote alarm in both the WESF operating gallery and shift office. The sample system also provides for alarms to high airborne radioactivity, high temperature in the stack monitoring cabinet, and system failure. Backup power is available to both of the K-1 HVAC system exhaust fans. The sample probe assembly and installation drawings are $\mathrm{H}-2-91142$, sht 1 of 1 , and $\mathrm{H}-2-92507$, Sht 1-4.

\subsection{ALTERNATIVE MONITORING AND ASSESSMENT METHODS}

A letter was issued by the Department of Health (Letter \#AIR-98-803) requiring measurements to demonstrate that the current configuration of the 296-B-10 stack provide the required NESHAP design equivalency. In response to this letter, two actions were performed by BWHC. A line-loss calculation was performed on the stack sampler using the Deposition 4.0 model and a velocity profile was measured to demonstrate that the stack flow is well developed at the sampler. These results were submitted to the Department of Health via letter RL-99-EAP-109, "National Emission Standards for Hazardous Air Pollutants (NESHAP), Request for Stack 296-B-10 Sample System Equivalency, Waste Encapsulation and Storage Facility (WESF)." 
HNF-4200, Rev. 0

\subsection{HISTORICAL MONITORINGISAMPLING DATA FOR EFFLUENT STREAMS}

Data generated from routine sampling of the WESF liquid and air effluents have, historically, focused on the radiological constituents of both efiluent streams. The liquid streams were characterized for radiological and nonradiological compounds in the Liquid Effluent Study Project conducted during 1989 and 1990. Data for liquid effluents are discussed in Section 8.1.1. The air effluents have not been routinely sampled for nonradiological constituents. Data for all air effluents are discussed in Section 8.1.2.

\subsection{NORMAL CONDITIONS}

This section presents historical monitoring and sampling data for liquid effluent streams under normal conditions.

\subsubsection{Liquid Effluent Streams}

Sampling data used in this analysis comes from both the waste stream characterization for the routine operation configuration and the feed source data that is used as background.

The sampling scheme took representative samples by following Test Methods for Evaluating Solid Wastes (SW-846) procedure sampling and analytical protocol (EPA 1986a). In some cases, American Society for Testing and Materials (ASTM) procedures were used when more appropriate than Test Methods for Evaluating Solid Wastes. This was accomplished by taking grab samples on a partitioned time random basis.

The details of the sampling, analytical, quality control, and quality assurance (QA) procedures used are contained in the Waste Stream Characterization Report (WHC 1989d).

\subsubsection{WLE}

During past operations, this stream was referred to as the B Plant Chemical Sewer (BCE) because B Plant was the primary contributor. Until February 27, 1992, the BCE stream was sampled at the 216-B63 Ditch. As of February 29, 1992, the BCE was no longer discharged to the 216-B-63 Ditch in accordance with TPA Milestone M-17-04B. Until 1995, the BCE combined with the B Plant Cooling Water and discharged to the 216-B-3 Pond. In 1995, the BCE was disconnecied from the CBC stream and routed to TEDF at pump station \#2. This line is now referred to as the WESF Liquid Effluent (WLE) stream. The results of sampling for TEDF from 4/95 through 7/97 are presented in Table 8-1. The requirements of WAC 173-303-070 (WAC 1990) and the waste stream characteristic data found in WHC-EP-0342 (WHC 1990a) support the contention that the WLE is not a dangerous waste stream. 
HNF-4200, Rev. 0

\subsubsection{Sanitary Sewers}

No data is available for the sanitary sewers.

\subsubsection{French Drains}

No data is available for the French drains 
Table 8-1 Statistical Data for the WESF Liquid Effluent (WLE) TEDF Tie-In.

Data were taken from historical data collected $4 / 95$ through $7 / 97$

\begin{tabular}{|c|c|c|c|c|}
\hline Constituant & Average & $\begin{array}{l}\text { Max. Detected } \\
\text { Concentration }\end{array}$ & $\begin{array}{l}\text { Standard } \\
\text { Deviation }\end{array}$ & $\begin{array}{l}\text { TEDF ICD } \\
\text { Target Linuts }\end{array}$ \\
\hline BIS(2-Ethylhexyl) Phthalate & 39 ugil & 46 ugh & 8.185 & $10^{\mathrm{a}}$ \\
\hline Aluminum & N/A & 78 ugh & N/A & \\
\hline Arsenic & $.9 u g h$ & $1.2 \mathrm{ug} / \mathrm{L}$ & .264 & $15^{a}$ \\
\hline Cadmium & $N / A^{1}$ & $.2 \mathrm{ug} /$ & N/A & $5^{b}$ \\
\hline Chromium & N/A1 & $2.5 \mathrm{ug} / \mathrm{L}$ & $N / A$ & $20^{b}$ \\
\hline Iron & 73 ugh & $125 \mathrm{ug} / \mathrm{L}$ & 25.638 & $258^{a}$ \\
\hline Lead & .571 ugh & $1 \mathrm{ug} / \mathrm{L}$ & .213 & $10^{b}$ \\
\hline Manganese & $6.33 \mathrm{ugh}$ & $9 \mathrm{ug} / \mathrm{L}$ & 2.516 & $50^{a}$ \\
\hline Mercury & NiA & .1 ugiL & N/A & $2^{a}$ \\
\hline Chloride & $1.46 \mathrm{mgh}$ & $2.12 \mathrm{mgh}$ & .557 & $58,000^{\mathrm{a}}$ \\
\hline Cyanide & $\mathrm{ND}^{4}$ & N/A & N/A & $50^{\circ}$ \\
\hline Nitrate & $.211 \mathrm{mg} / \mathrm{L}$ & $.333 \mathrm{mg} / \mathrm{L}$ & .082 & $620^{\mathrm{a}}$ \\
\hline Sulfate & $8.403 \mathrm{mgl}$ & $8.96 \mathrm{mgh}$ & .407 & None \\
\hline Phenol & $N^{4}$ & N/A & N/A & $10^{a}$ \\
\hline Oil and Grease & $N / A^{1}$ & $8.7 \mathrm{ugh}$ & N/A & None \\
\hline WTPH-G & $N^{4}$ & N/A & N/A & None \\
\hline Carbon Tetrachloride & $\mathrm{ND}^{4}$ & N/A & N/A & $5^{a}$ \\
\hline Chloroform & $\mathrm{ND}^{4}$ & NIA & N/A & None \\
\hline Gross alpha & $2.045 \mathrm{pCiL}$ & $3.63 \mathrm{pCil}$ & 2.241 & $15 \mathrm{pCiLL}$ \\
\hline Gross Beta & N/A 1 & $.79 \mathrm{pCil}$ & N/A & $50 \mathrm{pCil}$ \\
\hline Strontium-90 & $\mathrm{ND}^{4}$ & N/A & N/A & $8 \mathrm{pCil}$ \\
\hline Methylene Chloride & $\mathrm{ND}^{4}$ & N/A & N/A & $5^{a}$ \\
\hline 1,1,1 - Trichlorcethane & $\mathrm{ND}^{4}$ & N/A & N/A & $5^{b}$ \\
\hline Trihalomethanes (Total) & $\mathrm{NO}^{4}$ & N/A & N/A & $55^{b}$ \\
\hline Total Dissolved solids & 80,750 ugil & 102,000 ugh & 23.056 .091 & $250,000^{\mathrm{a}}$ \\
\hline
\end{tabular}

Data above minimum detection limits for one data point only. Data above minimum detection level placed in maximum column.

'Limits are in ug/L as specified in the State Waste Discharge Permit (Ecology 1995)

aState Waste discharge Permit Enforcement Limits in Effluent

${ }^{\circ}$ State Waste Discharge Permit Early Warning Values in Effluent

${ }^{\circ}$ State Waste Discharge Permit Enforcement Limits in Groundwater

${ }^{4}$ All measurements taken below minimum detectable levels.

Source: Liquid Effluent Monitoring Information System (LEMIS), Laboratory Data Statistical Report, 200 Area TEDF Interface Control Document, 1/1/92 through 9/29/97. 
Table 8-2 Statistical Data for the WESF Cooling Water (WCW) TEDF Tie-In. Data were taken from historical data collected $1 / 95$ through $7 / 97$

\begin{tabular}{|c|c|c|c|c|}
\hline Constituant & Average & $\begin{array}{l}\text { Max. Detected } \\
\text { Concentration }\end{array}$ & $\begin{array}{l}\text { Standard } \\
\text { Deviation }\end{array}$ & $\begin{array}{l}\text { TEDF ICD Target } \\
\text { Limits }^{2}\end{array}$ \\
\hline BIS(2-Ethylhexyl) Phthalate & N/A & 8 ugh/ & N/A & $10^{\mathrm{a}}$ \\
\hline Aluminum & N/A 1 & 417 & $\mathrm{~N} / \mathrm{A}$ & \\
\hline Arsenic & N/A ${ }^{1}$ & $.7 \mathrm{ugh}$ & N/A & $15^{a}$ \\
\hline Cadmium & .433 ug/L & $.6 \mathrm{ugh}$ & .152 & $5^{b}$ \\
\hline Chromium & N/A 1 & 1.5 ugil. & N/A & $20^{\mathrm{b}}$ \\
\hline Iron & $1870 \mathrm{ug} / \mathrm{L}$ & 3410 ugh & 1333.716 & $258^{a}$ \\
\hline Lead & 14 ugh & $35.9 \mathrm{ug} / \mathrm{L}$ & 18.973 & $10^{b}$ \\
\hline Manganese & 171 ught & $267 \mathrm{ug} / \mathrm{L}$ & 135.764 & $50^{a}$ \\
\hline Mercury & $.1 \mathrm{ugh}$ & $.1 \mathrm{ugh}$ & 0 & $2^{\circ}$ \\
\hline Chloride & N/A 1 & $22.5 \mathrm{mg} / \mathrm{L}$ & N/A & $58,000^{\mathrm{a}}$ \\
\hline Cyanide & $\mathrm{ND}^{4}$ & N/A & N/A & $50 \mathrm{ug} / \mathrm{L}^{\mathrm{b}}$ \\
\hline Nitrate & $N / A^{1}$ & $1.08 \mathrm{mg} / \mathrm{L}$ & N/A & $620^{\mathrm{s}}$ \\
\hline Sulfate & N/A' & $97.2 \mathrm{mg} / \mathrm{L}$ & N/A & None \\
\hline Phenol & $\mathrm{ND}^{4}$ & N/A & N/A & $10^{a}$ \\
\hline Oil and Grease & $\mathrm{ND}^{4}$ & $8.7 \mathrm{ug} / \mathrm{h}$ & N/A & None \\
\hline WTPH-G & $\mathrm{ND}^{4}$ & N/A & N/A & None \\
\hline Carbon Tetrachloride & $\mathrm{ND}^{4}$ & N/A & N/A & $5^{a}$ \\
\hline Chloroform & $N / A^{1}$ & 5 & N/A & None \\
\hline Gross alpha & $\mathrm{ND}^{4}$ & N/A & N/A & $15 \mathrm{pCilL}$ \\
\hline Gross Beta & $N^{\prime} A^{1}$ & $4.9 \mathrm{pCil}$ & N/A & $50 \mathrm{pCil}$ \\
\hline Strontium-90 & $\mathrm{ND}^{4}$ & N/A & N/A & $8 \mathrm{pCil}$ \\
\hline Methylene Chloride & $\mathrm{ND}^{4}$ & N/A & N/A & $5^{a}$ \\
\hline 1,1,1 - Trichloroethane & $\mathrm{ND}^{4}$ & N/A & N/A & $5^{b}$ \\
\hline Trihalomethanes (Total) & $N^{\prime} A^{1}$ & 5 & N/A & $55^{b}$ \\
\hline Total Dissolved solids & N/A 1 & 439,000 ug $\mathrm{L}$ & N/A & $250,000^{a}$ \\
\hline
\end{tabular}

Data above minimum detection limits for one data point only. Data above minimum detection level placed in maximum column.

${ }^{2}$ Limits are in ug/L as specified in the State Waste Discharge Permit (Ecology 1995)

${ }^{8}$ State Waste discharge Permit Enforcement Limits in Effluent

${ }^{\mathrm{D}}$ State Waste Discharge Permit Early Warning Values in Effluent

${ }^{c}$ State Waste Discharge Permit Enforcement Limits in Groundwater

4 All measurements taken below minimum detectable levels.

Source: Liquid Effluent Monitoring Information System (LEMIS), Laboratory Data Statistical Report, 200 Area TEDF Interface Control Document, 1/1/92 through 9/29/97. 


\subsubsection{WCW}

The results of sampling the WCW for TEDF are presented in Table 8-2. This stream became active in February, 1997 and limited historical data is available.

\subsubsection{Air Effluent Streams}

The monitoring system associated with the WESF main stack provides data on the radiological components of the air effluent from the WESF operations. Data on concentrations of gross alpha and gross beta emission for the years 1980 to 1995 from the main WESF stack is shown in Table 8-4. All emissions were below the Hanford ACV values in 1995. Available data on specific radionuclides emitted from the 296-B-10 stack are included in Table 8-3.

Table 8-3 Annual Radionuclide Emissions from the 296-B-10 Stack.

\begin{tabular}{|c|c|c|c|c|c|}
\hline Radionuclide & $\begin{array}{c}1992 \\
\text { Concentration } \\
\text { (ICimL) }\end{array}$ & $\begin{array}{c}1993 \\
\text { Concentration } \\
\text { (CimL) }\end{array}$ & $\begin{array}{c}1994 \\
\begin{array}{c}\text { Concentration } \\
\text { (CínL) }\end{array} \\
\end{array}$ & $\begin{array}{c}1995 \\
\text { Concentration } \\
\text { (JCiml) } \\
\end{array}$ & $\begin{array}{c}1996 \\
\begin{array}{c}\text { Concentration } \\
\text { (\{CimL })\end{array} \\
\end{array}$ \\
\hline $90 \mathrm{Sr}$ & $6.3 \mathrm{E}-15$ & 1.1E-14 & $1.7 \mathrm{E}-14$ & $1.5 \mathrm{E}-14$ & $3.5 \mathrm{E}-14$ \\
\hline${ }^{137} \mathrm{Cs}$ & $<4.7 \mathrm{E}-15$ & $1.6 \mathrm{E}-14$ & $8.7 \mathrm{E}-15$ & $7.1 \mathrm{E}-15$ & $1.5 \mathrm{E}-14$ \\
\hline 239.241Pu & $<6.9 \mathrm{E}-16$ & $<1.0 \mathrm{E}-15$ & $8.0 E-16$ & $1.3 \mathrm{E}-18$ & $1.3 \mathrm{E}-17$ \\
\hline${ }^{241} \mathrm{Am}$ & $1.7 \mathrm{E}-15$ & $<2.8 \mathrm{E}-15$ & $\begin{array}{c}\text { No data } \\
\text { available }\end{array}$ & $3.2 E-17$ & $3.6 \mathrm{E}-17$ \\
\hline
\end{tabular}

Data for theWESF Stack is contained in WHC-EP-0141 (WHC 1990e), WHC-EP-0527 (1991d), WHC-EP-0527-1 (WHC 1992C), WHC-EP-0527-2 (WHC 1993a), WHC-EP-0527-3 (WHC 1994A), WHCEP-0527-4 (WHC1995), and WHC-EP-0527-5 (WHC1996), and DOE/RL-97-43(1996). Data for the deactivated stacks can also be found in the above documentation. 


\subsection{UPSET CONDITIONS}

A review of all available documentation delineated that there are no upset conditions relevant to the current liquid receiving sites.

Table 8-4 WESF Air Effluent System Radiological Dataa.

\begin{tabular}{|c|c|c|}
\hline & Year & 296-B-10 \\
\hline 1995 & $\begin{array}{l}\alpha \\
\beta\end{array}$ & $\begin{array}{l}4.8 \mathrm{E}-16 \\
3.5 \mathrm{E}-14\end{array}$ \\
\hline 1994 & $\begin{array}{l}\alpha \\
\beta\end{array}$ & $\begin{array}{c}\text { Not Detectable } \\
7.7 \mathrm{E}-14\end{array}$ \\
\hline 1993 & $\begin{array}{l}\alpha \\
\beta\end{array}$ & $\begin{array}{l}<6.4 \mathrm{E}-17 \\
t .8 \mathrm{E}-13\end{array}$ \\
\hline 1992 & $\begin{array}{l}\alpha \\
\beta \\
\end{array}$ & $\begin{array}{c}<3.0 \mathrm{E}-16 \\
1.6 \mathrm{E}-14\end{array}$ \\
\hline 1991 & $\begin{array}{l}\alpha \\
\beta\end{array}$ & $\begin{array}{l}<2.8 \mathrm{E}-16 \\
2.3 \mathrm{E}-14\end{array}$ \\
\hline 1990 & $\begin{array}{l}\alpha \\
\beta \\
\end{array}$ & $\begin{array}{l}<6.0 \mathrm{E}-16 \\
5.7 \mathrm{E}-14 \\
\end{array}$ \\
\hline 1989 & $\begin{array}{l}\alpha \\
\beta\end{array}$ & $\begin{array}{l}<3.50 \mathrm{E}-15 \\
3.63 \mathrm{E}-14 \\
\end{array}$ \\
\hline 1988 & $\begin{array}{l}\alpha \\
\beta\end{array}$ & $\begin{array}{l}<3.50 \mathrm{E}-15 \\
4.14 \mathrm{E}-14\end{array}$ \\
\hline 1987 & $\begin{array}{l}\alpha \\
\beta\end{array}$ & $\begin{array}{l}<3.49 \mathrm{E}-15 \\
<1.73 \mathrm{E}-14 \\
\end{array}$ \\
\hline 1986 & $\begin{array}{l}\alpha \\
\beta \\
\end{array}$ & $\begin{array}{l}<3.51 \mathrm{E}-15 \\
8.55 \mathrm{E}-14\end{array}$ \\
\hline 1985 & $\begin{array}{l}\alpha \\
\beta\end{array}$ & $\begin{array}{l}<3.52 E-15 \\
-8.12 E-14 \\
\end{array}$ \\
\hline 1984 & $\begin{array}{l}\alpha \\
\beta \\
\end{array}$ & $\begin{array}{l}<3.52 \mathrm{E}-15 \\
8.23 \mathrm{E}-12 \\
\end{array}$ \\
\hline 1983 & $\begin{array}{l}\alpha \\
\beta\end{array}$ & $\begin{array}{l}<3.24 \mathrm{E}-15 \\
<2.32 \mathrm{E}-14\end{array}$ \\
\hline 1982 & $\begin{array}{l}\alpha \\
\beta\end{array}$ & $\begin{array}{l}<3.50 \mathrm{E}-15 \\
3.64 \mathrm{E}-14\end{array}$ \\
\hline 1981 & $\begin{array}{l}\alpha \\
\beta \\
\end{array}$ & $\begin{array}{l}<4.20 \mathrm{E}-14 \\
5.90 \mathrm{E}-13\end{array}$ \\
\hline 1980 & $\begin{array}{l}\alpha \\
\beta\end{array}$ & $\begin{array}{l}5.55 E-14 \\
8.93 E-13\end{array}$ \\
\hline
\end{tabular}

aAll data are in $\mu \mathrm{Ci} / \mathrm{mL}$.

Source: Annual Environmental Releases Calendar Year Reports. 
HNF-4200, Rev. 0

\subsection{SAMPLE ANALYSIS}

\subsection{ANALYTICAL LABORATORY AND PROCEDURES}

The analytical and laboratory procedures for the FEMP activities are identified in quality assurance project plans (QAPjP), one quality assurance program plan (QAPP), and the annual statement of work as follows:

- WHC-EP-0446-2, Quality Assurance Project Plan for the Facility Effluent Monitoring Plan Activities

HNF-EP-0528-3, NESHAP Quality Assurance Project Plan for Radioactive Airborne Emissions

- HNF-EP-0835-4, Statement of Work for Services Provided by the Waste Sampling and Characterization Facility for the Effluent and Environmental Program during Calendar Year 1998.

\subsubsection{Record Sample Exchange}

Sample identification is initiated by the operations group taking the sample. Sampling personnel use the Automated Bar Coding of Air Samples at Hanford (ABCASH) system to provide sample identification and chain of custody, which is performed through ABCASH electronically. Sample custody is transferred when the analytical laboratory receives the properly marked sample.

Along with all of the samples, which will be taken from the glove boxes, the record sampler filter paper and the CAM, sample filters will all be sent to an analytical laboratory. The Health Physics Technician performs the sample exchanges in the air sampling and monitoring devices. The following procedures are utilized: HNF-IP-0718, Health Physics Procedures, Section 3.3.2, Rev. 1, "Gaseous Effluent Monitoring System Inspection and Sample Exchange," and Section 3.3.3, Rev. 0, "Automated Bar Coding of Air Samples at Hanford," (ABCASH).

\subsubsection{CAM Filter Exchange}

CAM filters are exchanged per task number WESF-W-223, Rev. 01, formerly WHC-IP-0718, Section 3.3.2, Rev. 1, "Gaseous Effluent Monitoring System Inspection and Sample Exchange."

\subsubsection{Sample Data Examination and Delivery}

Sample Data examination and delivery to the Analytical Lab are conducted per HNF-IP-0718, Section 3.3.2, "Gaseous Effluent Monitoring System Inspection and Sample Exchange." 


\subsubsection{Laboratory Sample Analysis Instructions}

The Effluent Monitoring group assigns an Electronic Data Processing code to each discharge point monitoring and sampling equipment units.

Table 9-1 Minimum Detectable Concentrations for Specific Radionuclides as Measured in Air Samples

\begin{tabular}{|c|c|}
\hline Radionuclide & $\begin{array}{c}\text { Minimum Quantifiable Concentration } \\
\text { (uCi/mL) }\end{array}$ \\
\hline Total $\alpha$ & $2.0 \mathrm{E}-15$ \\
\hline Total $\beta$ & $1.9 \mathrm{E}-14$ \\
\hline GEA of Ag Zeolite (Ru-106) & $3.4 \mathrm{E}-13$ \\
\hline${ }^{239,240 \mathrm{Pu}}$ & $2.0 \mathrm{E}-15$ \\
\hline${ }^{238 \mathrm{Pu}}$ & $2.0 \mathrm{E}-15$ \\
\hline${ }^{241 \mathrm{Am}}$ & $1.9 \mathrm{E}-15$ \\
\hline${ }^{90 \mathrm{Sr}}$ & $1.9 \mathrm{E}-14$ \\
\hline${ }^{106 \mathrm{RuIRh}}$ & $3.4 \mathrm{E}-13$ \\
\hline
\end{tabular}

\subsubsection{Laboratory Analysis}

When the sample reaches the laboratory, the Record sample is held in the lab for seven days to allow the short lived natural occurring isotopes to decay. The sample is then counted for alpha and beta readings. These readings are reported to Effluent and Environmental Monitoring (EEM) and lab Health and Safety group. These samples are put in storage for further sampling. Quarterly, these samples are gathered and dissolved for radioanalysis. The results of these analyses are submitted and reported annually.

The CAM samples are not treated as record samples unless it is specifically requested. CAM filters from the stacks are managed by the Radiological Control group.

\subsubsection{Laboratory Procedures}

The analytical lab procedures are identified in the appendices of HNF-EP-0528-3, NESHAP Quality Assurance Project Plan for Radioactive Airborne Emissions. 


\subsection{SAMPLE AND DATA AND TRACKING}

Sample exchange procedures are specified in WHC-IP-0718, Section 3.3.2, "Gaseous Effluent Monitoring System Inspection and Sample Exchange." Tracking of samples and sample data is governed by Automated Bar Coding of Air Samples at Hanford.

Tracking of radioactive airborne emissions sample data is controlled by the Fluor Daniel Hanford (FDH) team (the Project Hanford Management Contractor) through assignment of unique electronic processing codes (EDP) for each sample location. The EDP codes are used by WSCF to report the results in accordance with the QAPjP for radioactive emissions data.

\subsection{U.S. DEPARTMENT OF ENERGY ANALYTICAL AND LABORATORY GUIDELINES}

The analytical and laboratory procedures for the radionuclide air emissions are identified in the NESHAP Quality Assurance Project Plan for Radioactive Airbome Emissions. General requirements for laboratory procedures, data analyses, and statistical treatment are addressed in the QAPjP. Detailed descriptions of these requirements are given in each FEMP.

The following elements identified in Environmental Regulatory Guide for Radiological Effluent Monitoring and Environmental Surveillance, DOE/EH-0173T are addressed in Quality Assurance Program Plan for Laboratory Analysis and Process Testing, WHC-SD-CP-QAPP-003 (WHC 1994d), and Quality Assurance Project Plan for Chemical Analysis of Highly Radioactive Mixed Waste Samples in Support of Environmental Activities on the Hanford Site, WHC-SD-CP-QAPP-002.

Procedures preventing cross contamination

Documentation of Methods

- Calibration

Handling of Samples

Analysis method and capabilities

Gross alpha, beta, and gamma measurements

- Direct gamma-ray spectrometry

- Beta counters

Alpha-energy analysis

Radiochemical separation procedures

Reporting of Results

Counter Calibration

Inter-calibration of equipment and procedures

- Counter background

- Quality assurance 
Table 9-2 Data Analyses and Statistical Treatment

\begin{tabular}{|l|l|}
\hline \multicolumn{1}{|c|}{ Element } & \multicolumn{1}{|c|}{ Documentation } \\
\hline $\begin{array}{l}\text { Summary of data and statistical treatment } \\
\text { requirements }\end{array}$ & WHC-SD-CP-QAPP-003, Rev. 1 \\
\hline Variability of effluent and environmental data & $\begin{array}{l}\text { HNF-EP-0527-7, Environmental Releases for } \\
\text { Calendar Year 1997, August 1998 }\end{array}$ \\
\hline Summarization of data and testing for outliers & $\begin{array}{l}\text { Statistical identification of control standards is } \\
\text { performed by the Laboratory Measurement Control } \\
\text { System database program during the annual review } \\
\text { of data for setting control limits. Outliers are } \\
\text { evaluated. }\end{array}$ \\
\hline Treatment of significant figures & WHC-SD-CP-QAPP-003, Rev. 1 \\
\hline Parent-decay product relationships & $\begin{array}{l}\text { Parent-decay product relationships are not } \\
\text { accounted for in laboratory operating procedures. }\end{array}$ \\
\hline $\begin{array}{l}\text { Comparisons to regulatory or administrative control } \\
\text { standards and control data }\end{array}$ & $\begin{array}{l}\text { The WSCF laboratory participates in the EPA Inter- } \\
\text { Comparison Program }\end{array}$ \\
\hline Quality Assurance & WHC-SD-CP-QAPP-003, Rev. 1 \\
\hline
\end{tabular}


HNF-4200, Rev. 0

\subsection{NOTIFICATIONS AND REPORTING REQUIREMENTS}

Notifications and reporting of specific events related to environmental releases and/or events involving effluents and/or hazardous materials shall be made per DOE Orders 5400.1 (DOE 1991C) and 232.1 (DOE 1995). Implementation of the orders is accomplished via Project Hanford Policies and Procedures, HNF-PRO-060, Rev. 1 (1998). Specific implementation, where required, is included in the appropriate facility's occurrence categorization, notification, and reporting procedure. Implementation of environmental limits and requirements is found in the HNF-PRO-450.

\subsection{REQUIREMENTS}

\subsubsection{Occurrence Identification and Immediate Response}

10.1.1.1 Each employee shall identify appropriate events and conditions and shall promptly notify management of such occurrences. These actions may include, but are not limited to the following:

1. Call 911 if immediate help is required (e.g., fire department, ambulance, or patrol)

2. Call $373-3800$ (the Patrol Operations Center) if assistance other than fire, ambulance, or patrol is required

3. After requesting necessary outside assistance, the employee shall notify their supervisor, who shall notify the facility manager, the building emergency director, and the occurrence notification center (ONC) at 376-2900.

10.1.1.2 Operations personnel shall take appropriate immediate action to stabilize or return the facility/operation to a safe condition.

10.1.1.3 The oversight organizations shall notify their DOE Field Office and Richland counterparts of the event after receiving notifications from, and discussing the event with, the facility manager.

\subsection{OCCURRENCE CATEGORIZATION}

Occurrences shall be categorized as soon as practical using the specific criteria listed in Section 10.2 for radioactive and hazardous materials releases. These categorizations should be made within 2 hours of identification. Occurrences shall be categorized by their seriousness; if categorization is not clear, the occurrence shall be initially categorized at the higher level being considered. The occurrence categorization shall then be evaluated, maintained, or lowered as information becomes available.

The following criteria for categorization of occurrences are established in HNF-PRO-060, Rev. 0, which implements the requirements contained in DOE Order 232.1 (DOE 1995). 
HNF-4200, Rev. 0

\subsubsection{Radioactive Releases}

Radioactive releases are categorized into emergency, unusual occurrence, and off-normal. These categories are further defined as follows:

\subsubsection{Emergency}

- Any release of radioactive material to controlled or uncontrolled areas in concentrations that, if averaged over a period of 24-h, would exceed 5 times the respective reportable quantities (RQ) specified for such materials in 40 CFR 302 (EPA 1988). Note: This event must also meet the criteria for classified emergency in accordance with DOE-RL-94-02, Hanford Emergency Response Plan, and/or facility specific emergency action levels.

\subsubsection{Unusual Occurrence}

Release of radioactive material that violates environmental requirements in Federal permits, Federal regulations, or DOE standards.

- Release of radioactive material that exceeds a federally permitted release by the amount of a CERCLA RQ or, where no federally permitted release exists, the release exceeds the $R Q$.

Release below emergency levels that require immediate reporting to regulatory authorities or triggers specific action levels for an outside agency.

\subsubsection{Off-Normal}

- Any release of radionuclide material to controlled or uncontrolled areas that is not part of a normal monitored release and exceeds 50 percent of a CERCLA RQ specified for such material per 40 CFR 302 (EPA 1988).

- Any controlled radionuclide material release that occurs as a monitored part of normal operations that exceeds what historical data and/or analysis show is expected as a result of normal operations.

- Any monitored facility or site boundary where exposure or concentrations exceed what historical data and/or analysis show is expected as a result of normal operations.

- Any detection of a radionuclide in a sanitary or storm sewer, waste or process stream, or any holding points where such a material is not expected.

- Any controlled, uncontrolled, or accidental release that is not classified as an unusual occurrence but which will be reported in writing to state/local agencies in a format other than 
the routine monthly or quarterly reports. Note: This does not include routine off-site distribution of Notification Reports.

\subsubsection{Release of Hazardous Substances/Regulated Pollutants/Oil}

Hazardous substances releases are categorized into emergency, unusual occurrence, and offnormal. These categories are further defined as follows:

\subsubsection{Emergency}

- Any actual or potential release of material to the environment that results in, or could result in, significant offsite consequences (e.g., need to relocate people, major wildife kills, wetland degradation, and aquifer contamination, and the need to secure downstream water supply intakes. Note: This event must also meet the criteria for classified emergency in accordance with WHC-CM-4-1, Emergency Plan (WHC 1993h), and/or facility specific action levels.

- Any release of hazardous substances or regulated pollutants in concentrations that exceed five times the respective RQs specified for such materials in 40 CFR 302 (EPA 1988). Note: This event must also meet the criteria for classified emergency in accordance with WHC-CM-4-1, Emergency Plan (WHC 1993h), and/or facility specific action levels.

\subsubsection{Unusual Occurrence}

Release of a hazardous substance or regulated pollutant, or oil that violates environmental requirements in Federal permits, Federal regulations, or DOE standards.

- Release of a hazardous substance or regulated pollutant that exceeds a CERCLA RQ per 40 CFR 302 (EPA 1988) or exceeds a federally permitted release by an RQ.

C Release below emergency levels that require immediate reporting to Federal regulatory agencies or triggers specification levels for an outside agency.

Any release of 100 gallons or more of oil.

\subsubsection{Off-Normal}

Release of a hazardous substance or regulated pollutant to controlled or uncontrolled areas that is not part of a normal, monitored release and exceeds 50 percent of a CERCLA RQ as specified for such material per 40 CFR 302 (EPA 1988).

- Any release of oil less than the unusual occurrence level but greater than 10 gallons. 
- Any detection of a toxic or hazardous substance in a sanitary or storm sewer, waste or process stream, or any holding points where such a material is not expected.

- Any controlled, uncontrolled or accidental release that is not classified as an unusual occurrence but that will be reported in writing to state and local agencies in a format other than routine monthly or quarterly reports. Note: This does not include routine offsite distribution of Notification Reports.

- Any controlled release of hazardous and/or regulated material that occurs as a monitored part of normal operations that exceeds what historical data and/or analysis shows is expected as a result of normal operations

Any general environmental monitoring where concentration increases to a level that exceeds what historical data and/or analysis shows is expected as a result of normal operations.

\subsubsection{Discovery of Hazardous Material Contamination Due to U.S. Department of Energy Operations}

Discoveries of hazardous material contamination because DOE operations are categorized into emergency, unusual occurrence, and off-normal. These categories are defined as follows:

\subsubsection{Emergency}

D Discovery of contamination that results, or could result, in significant consequences (i.e., exceeding safe exposure limits to workers or public). Note: This event must also meet the criteria for classified emergency in accordance with DOE-0223, Emergency Plan Implementing Procedure, and/or facility specific action levels.

Discovery of onsite or offsite hazardous material contaminations in concentrations that exceed five times the respective RQs specified for such materials in 40 CFR 302 (EPA 1988). Note: This event must also meet the criteria for classified emergency in accordance with DOE-0223, Emergency Plan Implementing Procedure, and/or facility specific action levels.

\subsubsection{Unusual Occurrence}

- Discovery of offsite contamination because of DOE operations that do not represent an immediate threat to the public, but exceeds a reportable quantity for such materials per 40 CFR 302 (EPA 1988).

Discovery of groundwater contamination that is not part of an existing plume previously identified in either an annual report or in any CERCLA/RCRA activity report. 


\subsubsection{Off-Normal}

- Discovery of any onsite contamination attributable to DOE operations that exceeds 50 percent of the reportable quantity for such material per 40 CFR 302 (EPA 1988).

\subsubsection{Agreement and Compliance Activities}

Agreement and compliance activities are categorized into unusual occurrence and off-normal. These categories are defined as follows:

\subsubsection{Unusual Occurrence}

- Any agreement, compliance, remediation, or permit-mandated activity for which notification has been received from the relevant regulatory agency that a site plan is not satisfactory or that a site is considered to be in noncompliance with schedules or requirements. Note: Formal notification must be received by FDH of a subcontractor in writing.

- Any occurrence under any agreement or compliance area that requires notification of an outside agency within 4 hours or less, or triggers an outside regulatory agency action level, or otherwise indicates specific interests and/or concerns from such agencies. Note: Does not include notifications made for radionuclide and/or hazardous material releases that are less than 50 percent of the RQ as specified in 40 CFR 302 (EPA 1988).

\subsubsection{Off-Normal}

Any occurrence under any agreement of compliance area that will be reported to outside agencies in a format other than a routine monthly or quarterly report. Note: Does not include routine offsite distribution of notification reports.

\subsubsection{Ecological Resources} follows:

Ecological resources are categorized into unusual occurrences. This category is defined as

\subsubsection{Unusual Occurrence}

- Any occurrence causing significant impact to any ecological resource for which the DOE is a trustee (i.e., destruction of a critical habitat, damage to a historical or archeological site, and damage to wetlands). 
HNF-4200, Rev. 0

\subsection{INTERFACE WITH THE OPERATIONAL ENVIRONMENTAL MONITORING PROGRAM}

\subsection{DESCRIPTION}

The sitewide Environmental Monitoring Plan (EMP), DOE/RL-91-50, Rev 1; consists of two distinct but related components; environmental surveillance conducted by PNNL and effluent monitoring conducted by the FDH team. Environmental surveillance, conducted by PNNL, consists of surveillance of all environmental parameters to demonstrate compliance with regulations. Effluent monitoring includes in-line and facility effluent monitoring as well as near-facility environmental monitoring. Projected offsite doses, reported in this FEMP, are the products of effluent monitoring and source term evaluation. Near-field monitoring is required in accordance with procedures described in the operational environmental monitoring QAPJP.

\subsection{PURPOSE}

Near-Facility Monitoring (NFM) provides facility-specific environmental monitoring to protect the environment adjacent to facilities under the responsibility of the FDH team and to assure compliance with local, state, and federal environmental regulations.

The objectives of the NFM are to evaluate the following:

Compliance with DOE, EPA, Ecology, WDOH, and internal FDH team environmental radiation protection requirements and guides

- Performance of radioactive waste confinement systems

- Trends of radioactive materials in the environment at and adjacent to nuclear facilities and waste disposal sites.

Specifically, the NFM is developed to:

- Monitor all inactive, existing, and new low-level waste disposal sites to assess both radiological and nonradiological hazards (DOE Order 5820.2A).

- Determine the effectiveness of effluent treatment and controls in reducing effluents and emissions (DOE/EH-0173T).

- Detect and quantify unplanned releases (DOE/EH-0173T) (40 CFR 302) (WAC 173-303-145) (DOE 0 232.1) (DOE 5484.1).

- Monitor fugitive emissions and diffuse sources from contaminated areas for compliance with NESHAPs (40 CFR 61), (DOE/EH-0173T), Toxic Air Emissions Inventory (40 CFR 265, 
Subparts AA \& B13), State Operating Permit Program (40 CFR 70), and Source Registration (WAC 246-247).

C Monitor all surplus facilities before decontaminating or decommissioning (DOE Order 5820.2A).

nonitor new and existing sites, processes, and facilities for potential impacts and releases (DOE Order 5484.1 and DOE/EH-0173T).

Monitor and assess radioactive contamination and potential exposure to employees and the public (DOE Orders 5400.1\&5400.5).

The purpose and justification for the NFM includes the following:

- The NFM provides a level of assurance to the FDH team that the effluent and contamination controls for the various facilities and waste sites are effective.

A secondary aspect of the NFM is additional assurance beyond that provided by the Occupational Health and Safety Program that it is safe to work onsite and for visitors to safely tour the site.

\subsection{BASIS}

Near-facility monitoring is conducted to (1) monitor employee protection; (2) monitor environmental protection; and (3) ensure compliance with local, State, and Federal regulations.

\subsection{MEDIA SAMPLED AND ANALYSES PERFORMED}

Procedure protocols for sampling, analysis, data handling, and reporting are specified in WMNWCM-004. Media include ambient air, surface water, groundwater, external radiation dose, soil, sediment, vegetation, and animals at or near active and inactive facilities and/or waste sites. Parameters monitored include the following, as needed: $\mathrm{pH}$, water temperature, radionuclides, radiation exposure, and hazardous constituents. Animals that are not contaminated, as determined by a field instrument survey, are released to a nonhazardous environment.

\subsection{LOCATIONS}

Samples are collected from known or suspected effluent pathways (e.g., downwind of potential releases, liquid streams, or proximal to release points). To avoid duplication, the FDH team relies on sample locations where PNNL has previously established sample sites (e.g., air samplers in the 300 Area). There are approximately (numbers and locations may vary year to year) 60 air samplers 300 external radiation monitor points (survey points and thermoluminescent dosimeter (TLD)), 160 soil sample sites, and 95 vegetation sample sites. Animal samples are collected at or near facilities and/or waste sites. 
Surveys to detect surface radiological contamination, scheduled in HNF-SP-0098-10, are conducted near and on liquid waste disposal sites (e.g., cribs, trenches, drains, retention basin perimeters, pond perimeters, and ditch banks), solid waste disposal sites (e.g., burial grounds and trenches), unplanned release sites, tank farm perimeters, stabilized waste disposal sites, roads, and firebreaks in the Operations Areas.

\subsection{PROGRAM REVIEW}

The near-facility monitoring will be reviewed at least annually to determine that the appropriate effluents are being monitored and that the monitor locations are in position to best determine potential releases.

\subsection{SAMPLER DESIGN}

Sampler design (e.g., air monitors) will be reviewed at least biannually to determine equipment efficiency and compliance with current EPA and industry (e.g., ANSI and American Society for Testing and Materials [ASTM]) standards.

\subsection{COMMUNICATION}

The FDH team and the research and development contractor (PNNL) will compare and communicate results of their respective monitoring programs at least quarterly and as soon as possible under upset conditions.

\subsection{REPORTS}

Results of the NFM are published in annual reports, such as Environmental Releases for Calendar Year 1997, HNF-EP-0527-7, Near-Facility Environmental Monitoring Annual Report, Calendar Year 1997, HNF-EP-0573-6, and Radionuclide Air Emissions Report for the Hanford Site, Calendar Year 1997, DOE/RL-98-33. The radionuclide values in these reports are expressed in curies, for each radionuclide per unit weight of sample (e.g., picocuries per gram) or in field instrument values (e.g., counts per minute). Values are reported in this manner, rather than EDE, which is calculated as the summation of the products of the dose equivalent received by speciiied tissues of the body and a tissue-specific weighting factor. 
HNF-4200, Rev. 0

\subsection{QUALITY ASSURANCE}

\subsection{PURPOSE}

The PHMC Quality Assurance Policy, HNF-POL-QA describes the quality assurance (QA) requirements associated with implementing FEMPs. The plan identifies FEMP activities and assigns the appropriate requirements defined by the NESHAP Quality Assurance Project Plan for Radioactive Air Emissions Data, HNF-EP-0536. The QAPjP shall be consistent with the requirements in "Quality Assurance," DOE Order 5700.6C (DOE 1991b). In addition, QA requirements in 40 CFR 61 (EPA 1990a), Appendix B, Method 114 shall be considered when performing monitoring calculations and establishing monitoring systems for airborne emissions.

\subsection{OBJECTIVE}

The plan documents QA requirements for facilities implementing the FEMPS.

\subsection{REQUIREMENTS}

A HNF-POL-QA has been developed to implement the overall quality assurance program requirements defined by HNF-EP-0536 and 40 CFR 61, Appendix B, Method 114 (EPA 1991a). HNF-POLQA applies specifically to the field activities, laboratory analyses, and continuous monitoring performed for all FEMPs by BWHC. Plans and procedures referenced in the HNF-POL-QA are available for regulatory review upon request from the Fluor Daniel Hanford Environmental Assurance manager. The PHMC Quality Assurance Policy, HNF-POL-QA has been developed the quality assurance elements of 40 CFR 61, and has been submitted to the EPA. In addition, EPA regulations require that records of radioactive airborne emissions monitoring be maintained onsite for five years. Operations management shall maintain records of reports on measurements of stack particulates or other nonradioactive hazardous pollutant emissions for three years. 


\subsection{INTERNAL AND EXTERNAL PLAN REVIEW}

The DOE Order 5400.1, General Environmental Protection Program, Chapter IV.4 (DOE 1991C) requires an annual review of the facility effluent monitoring plan and an update every 3 years. The FEMP should also be reviewed and updated as necessary after each major change or modification in the facility processes, facility structure, ventilation and liquid collection systems, monitoring equipment, or waste treatment, or for a significant change to the safety analysis reports.

Although the report is based on the calendar year, the emission limits apply to any 12 consecutive month period. Waste Management Federal Services of Hanford, Inc. and Pacific Northwest National Laboratory prepares an annual effluent discharge report for each area on the Hanford Site to cover both airborne and liquid release pathways. In addition, a report on the air emissions and compliance to the NESHAP is prepared by Waste Management Federal Services of Hanford, Inc. and submitted to EPA as well as to DOE Headquarters.

Contractor management is responsible for assigning appropriate personnel to perform the required reviews, assessments, and approvals, and to maintain this documentation. The DOE may require additional reviews to ensure program integrity. 
HNF-4200, Rev. 0

\subsection{COMPLIANCE ASSESSMENT}

This section presents the conclusions reached from evaluating the effluent monitoring systems in terms of the following:

Does the system operate within regulatory requirements?

- Do the instrument specifications match the characteristics of the effluent streams?

Is the system capable of responding to upset conditions?

- If there are deficiencies in meeting regulatory compliance, what is needed to reach compliance?

\subsection{COMPLIANCE ASSESSMENT COMPARISONS}

\subsubsection{Comparison of Instrument Specifications with Required Standards}

\subsubsection{Liquid Streams}

The WLE and WCW streams are monitored for flow and $\mathrm{pH}$ to ensure the requirements established by TEDF are met. The pH limits established by the TEDF ICD are a minimum of 6.5 and a maximum of 8.5. The maximum flow ( $4 \mathrm{hr}$. average) for WLE is $105 \mathrm{gal} / \mathrm{min}$ and for WCW is $200 \mathrm{gal} / \mathrm{min}$.

\subsubsection{Air Effluents}

Inline monitoring instrumentation is generally adequate for process operation control in order to identify potential upset conditions. However, the inline monitoring instrumentation, in terms of sensitivity and nonspecificity, is not sufficient to meet regulatory requirements under NESHAPs (EPA 1991a); and therefore, continuous sampling and analysis of samples are necessary (see Section 3.3 and Tables 4-1 through 4-3). Subpart $H$ of the NESHAPs requires that radionuclide emissions from the site not cause an EDE to the maximally exposed individual in excess of $10 \mathrm{mrem} / \mathrm{yr}$. Radionuclide emissions from stacks and vents must be continuously measured at all release points having the potential to discharge radionuclides in excess of 1 percent of this standard (i.e., greater than $0.1 \mathrm{mrem} / \mathrm{yr}$ ). This potential must be based on the discharge that would occur if no engineering control equipment exists. Confirming the necessity for the monitoring, DOE/EH 0173T states, "Airborne emissions from DOE-controlled facilities that have the potential for causing doses exceeding 0.1 mrem EDE from emissions in a year shall be monitored in accordance with the requirements of DOE 5400.1 and DOE 5400.5" (DOE 1991a). 
Table 14-1 Regulatory Compliance of WESF Liquid Effluent Stream Monitors

\begin{tabular}{|c|c|c|c|c|c|c|c|}
\hline \multirow[b]{2}{*}{ Parameter } & \multicolumn{2}{|c|}{ Normal Operating range } & \multirow{2}{*}{$\begin{array}{c}\text { Potential } \\
\text { upset } \\
\text { discharge }\end{array}$} & \multicolumn{2}{|c|}{ Monitor range } & \multirow{2}{*}{$\begin{array}{c}\text { Monitor } \\
\text { Alarm } \\
\text { Point }\end{array}$} & \multirow{2}{*}{$\begin{array}{c}\text { Regulatory } \\
\text { limite }\end{array}$} \\
\hline & Minimum & Maximum & & Minimum & Maximum & & \\
\hline $\begin{array}{l}\text { WLE } \\
\text { pH(pH units) }\end{array}$ & 5.22 & 7.67 & $2<>12.5$ & 0 & 14 & $\begin{array}{l}6.5 \mathrm{lo} \\
8.5 \mathrm{hi}\end{array}$ & $2.0-12.5$ \\
\hline Flow & $3 \mathrm{gpm}$ & $15 \mathrm{gpm}$ & Not Available & 0 & $600 \mathrm{gpm}$ & None & $\begin{array}{c}<200 \text { gpm } \\
\text { averaged over } \\
4 \text { hours }\end{array}$ \\
\hline $\begin{array}{l}\text { WCW } \\
\text { pH (pH units) }\end{array}$ & 7.0 & 8.35 & 8.5 & 0 & 14 & $\begin{array}{l}6.5 \mathrm{lo} \\
8.5 \mathrm{hi}\end{array}$ & $\begin{array}{l}6.5 \mathrm{lo} \\
8.5 \mathrm{hi}\end{array}$ \\
\hline Flow & 0 & $100 \mathrm{gpm}$ & Not available & 0 & $100 \mathrm{gpm}$ & None & $105 \mathrm{gpm}$ \\
\hline Conductivity & $300 \mu \mathrm{S} / \mathrm{cm}$ & $400 \mu \mathrm{S} / \mathrm{cm}$ & $800 \mu S / \mathrm{cm}$ & 0 & $600 \mu S / c m$ & None & None \\
\hline
\end{tabular}

aLimits taken from Treated Effluent Disposal Facility Interface Control Data, HNF-SD-W049H-ICD-001, Rev. 4

Table 14-2 Comparison of Regulatory and Lab Analytical Detection Limits

\begin{tabular}{|c|c|c|c|}
\hline Parameter & Analysis basis & Minimum detection limit ( $(\mathrm{CC} / \mathrm{mL})$ & Regulatory limit \\
\hline \multicolumn{4}{|c|}{ Air } \\
\hline $\operatorname{sos} r$ & $\begin{array}{l}\text { Monthly } \\
\text { Quarterly }\end{array}$ & $\begin{array}{l}2.0 \mathrm{E}-14 \\
7.0 \mathrm{E}-15\end{array}$ & $9.0 \mathrm{E}-12 \mu \mathrm{Ci} / \mathrm{mL}$ \\
\hline${ }^{137} \mathrm{Cs}$ & $\begin{array}{l}\text { Monthly } \\
\text { Quarterly }\end{array}$ & $\begin{array}{l}7.0 \mathrm{E}-15 \\
2.0 \mathrm{E}-15\end{array}$ & $4.0 \mathrm{E}-10 \mu \mathrm{Ci} / \mathrm{mL}$ \\
\hline $239.240 \mathrm{Pu}$ & $\begin{array}{l}\text { Monthly } \\
\text { Quarterly }\end{array}$ & $\begin{array}{l}4.0 \mathrm{E}-15 \\
1.0 \mathrm{E}-15\end{array}$ & $2.0 \mathrm{E}-14 \mu \mathrm{Ci} / \mathrm{mL}^{\mathrm{s}}$ \\
\hline \multicolumn{4}{|c|}{ Water } \\
\hline Gross alpha & Semi-Annual & $2.0 E-09$ & $15 \mathrm{pCils}$ \\
\hline Gross beta & Semi-Annual & $8.0 \mathrm{E}-09$ & $50 \mathrm{pCi} /{ }^{\circ}$ \\
\hline $90 \mathrm{Sr}$ & Semi-Annual & $2.0 \mathrm{E}-08$ & $8 \mathrm{pCilic}$ \\
\hline
\end{tabular}

\&Regulatory limit below lab analytical detection limit.

bRegulatory limits taken from (WHC 1993b) and (DOE 1990b).

GTEDF ICD limits

Tables 4-1 through 4-2 calculate the percent of the offsite regulatory limits to the maximally exposed individual for both pre- and post-control conditions for the WESF stacks. Based on the information contained in these tables, monitoring of gross alpha, beta, Cs-137, and Sr-90 are sufficient, since regulations require isotope-specific analysis only for isotopes that may contribute greater than 10 percent of the potential EDE for each release point of sites that require continuous emissions measurement. 
A point-by-point evaluation of the NESHAP requirements was conducted by the facility. The findings of this evaluation are documented in WESF Comparison with 40 CFR 61, Subpart $\mathrm{H}$, and Other Referenced Guidelines for Stack 296-B-10, HNF-EP-0546 (WHC 1992e).

\subsubsection{Comparison of Instrument Specifications with Monitoring Criteria}

No problems were identified.

\subsubsection{Comparison of Instrument Specifications with Effluent Characteristics}

No major problems were identified in comparing the instrument specifications to the effluent characteristics. Based on the information shown in Table 14-1, the monitoring system will respond to both normal and upset concentrations.

\subsubsection{Comparison of Projected Effluent Characteristics with Historical Data}

A comparison of the projected liquid effluent characteristics with the historical data (see Tables 8-1, and 8-2) indicates a reasonable agreement with releases during routine operational conditions. All process streams are now diverted to TEDF.

The projection of gaseous effluent data is essentially the same as the historical record. The identified upset condition would cause the alarm system to react.

\subsubsection{Comparison of Effluent Monitoring Capabilities with Regulatory and Contractor Requirements}

Liquid effluents are monitored satisfactorily to meet TEDF ICD requirements.

Routine radiological monitoring and sampling of gaseous effluents consist of total alpha and beta Cs-137 and Sr-90 analyses. In accordance with DOE/EH-0173T, those gaseous emission points with the potential to contribute greater than 10 percent of the offsite dose limits are continuously measured for specific radionuclides (DOE 1991a). In-line monitoring for gross radioactivity is adequate for process operation control for gaseous effluents in order to identify potential upset conditions.

\subsection{EXEMPTIONS}

There are no valid or pending exemptions identified for the WESF effluents.

\subsection{SYSTEM UPGRADES REQUIRED FOR COMPLIANCE}

No upgrades are planned at this time. 


\subsection{SUMMARY AND CONCLUSIONS}

The major liquid effluents include the WESF Cooling Water (WCW) system and the WESF Liquid Effluent (WLE) systems. The major gaseous effluents include the 296-B-10.

\subsection{LIQUID EFFLUENTS}

The liquid effluent monitoring systems respond satisfactorily to both normal and upset radionuclide concentrations. The only nonradiological monitoring parameter for which analyses are routinely performed is $\mathrm{pH}$ and flow.

If spills or upsets occur, sampling should be conducted for any contaminants that have the potential to exceed regulatory limits.

\subsection{GASEOUS EFFLUENTS}

Inline monitoring instrumentation is generally adequate for process operation control to identify potential upset conditions. However, in-line monitoring instrumentation is not sufficiently sensitive to meet NESHAPs (EPA 1991a) regulatory requirements. Therefore stacks and vents exceeding 1 percent of the 10 rem/yr standard must be continuously measured, and all radionuclides contributing greater than 10 percent of the total dose from the stack must be measured (see Section 14.1.1.2)].

The findings of a point-by-point evaluation of the NESHAP requirements are documented in WESF Comparison with 40 CFR 61, Subpart $H$, and Other Referenced Guidelines for Stack 296-B-10, HNF-EP-0546 (WHC 1992e).

A letter was issued by the Department of Health (Letter \#AIR-98-803) requiring measurements to demonstrate that the current configuration of the 296-B-10 stack provide the required NESHAP design equivalency. In response to this letter, two actions were performed by BWHC. A line-loss calculation was performed on the stack sampler using the Deposition 4.0 model and a velocity profile was measured to demonstrate that the stack flow is well developed at the sampler. These results were submitted to the Department of Health via letter RL-99-EAP-109, "National Emission Standards for Hazardous Air Pollutants (NESHAP), Request for Stack 296-B-10 Sample System Equivalency, Waste Encapsulation and Storage Facility (WESF)." 
HNF-4200, Rev. 0

\subsection{REFERENCES}

29 CFR 1910, 1994, "Occupational Health and Safety Standards," Code of Federal Regulations, as amended.

40 CFR 60, 1990, "Standards of Performance for New Stationary Sources," Code of Federal Regulations, as amended.

40 CFR 61, Subpart H, 1989, "National Emission Standards for Hazardous Air Pollutants (NESHAP)," Code of Federal Regulations, as amended.

40 CFR 70, 1992, "State Operating Permit Program," Code of Federal Regulations, as amended.

40 CFR 261, 1989, "Identification and Listing of Hazardous Waste, Code of Federal Regulations, as amended.

40 CFR 262, 1988, "Standards Applicable to Generators of Hazardous Waste," Code of Federal Regulations, as amended.

40 CFR 264, 1989, "Standards for Owners and Operators of Hazardous Waste Treatment, Storage, and Disposal Facilities," Code of Federal Regulations, as amended.

40 CFR 265, 1989, "Interim Status for Owners and Operators of Hazardous Waste Treatment, Storage, and Disposal Facilities," Code of Federal Regulations, as amended.

40 CFR 302, 1991, "EPA Designation, Reportable Quantities, and Notification Requirements for Hazardous Substances Under CERCLA," Code of Federal Regulations, as amended.

40 CFR 355, 1987, "Superfund Amendments and Reauthorization Act of 1986 (SARA): Emergency Planning and Notification, Code of Federal Regulations, as amended.

40 CFR 401-471, 1990, "Effluent Guidelines Standards," Code of Federal Regulations, as amended.

ANSI, 1969, Guide to Sampling Airborne Radioactive Materials in Nuclear Facilities, ANSI N13.1, American National Standards Institute, New York, New York.

ANSI, 1974, Specification and Performance of Onsite Instrumentation for Continuously Monitoring Radioactivity in Effluents, ANSI N42.18-1974, American National Standards Institute, New York, New York.

Benton Clean Air Authority, Regulation 1, Kennewick, Washington.

DOE Order 5000.3b, Occurrence Reporting and Processing of Operations Information, 1993, U.S. Department of Energy, Washington, D.C. 
DOE Order 5484.1, Environmental Protection, Safety, and Health Protection Information Reporting Requirements, 1981, U.S. Department of Energy, Washington, D.C.

DOE Order 5820.2A, Radioactive Waste Management, 1988, U.S. Department of Energy, Washington, D.C.

DOE/EH-0096, A Guide for Effluent Radiological Measurements at DOE Installations as amended, 1983, U.S. Department of Energy, Richland Operations Office, Richland, WA.

DOE/EV/1830-T5, A Guide to Reducing Radiation Exposure to As Low As Reasonably Achievable (ALARA), 1991, U.S. Department of Energy, Washington, D.C.

DOE/EH-0173T, Environmental Regulatory Guide for Radiological Effluent Monitoring and Environmental Surveillance, 1991, U.S. Department of Energy, Washington, D.C.

DOE/RL-93-18, Plan and Schedule for Disposition and Regulatory Compliance for Miscellaneous Streams, 1994, as amended, U.S. Department of Energy, Richland Operations Office, Richland, WA.

DOE/RL-95-82, Inventory of Miscellaneous Streams, as amended, 1995, U.S. Department of Energy, Richland Operations Office, Richland, WA

DOE/RL-98-33, Radionuclide Air Emissions Report for the Hanford Site, Calendar Year 1997, June 1998, U.S. Department of Energy, Richland Operations Office, Richland, WA.

EPA, Authorization to Discharge Under the National Pollutants Discharge Elimination System, NPDES, Permit WA-000374-3, 1981, U.S. Environmental Protection Agency, Washington, D.C.

Federal Clean Air Act of 1977, 42 USC 7401 et seq.

Federal Water Pollution Control Act of 1972, 33 USC 1251 et seq.

Resource Conservation and Recovery Act of 1976, 42 USC 6901 et seq.

Safe Drinking Water Act of 1974,42 USC 300 f et seq.

Superfund Amendment and Reauthorization Act of 1986, 42 USC 11001 et seq.

HNF-EP-0527-7, Environmental Releases for Calendar Year 1997, current revision, Fluor Daniel Hanford Company, Richland, Washington.

HNF-PRO-222, Quality Assurance Records, Fluor Daniel Hanford, Inc., Richland, Washington, 1996. 
HNF-PRO-224, Document Control and Records Management, Fluor Daniel Hanford, Inc., Richland, Washington, 1996.

HNF-PRO-450, Air Quality Program, 1998, Fluor Daniel Hanford, Inc., Richland, Washington.

HNF-PRO-453, Environmental Notification and Reporting, 1998, Fluor Daniel Hanford, Inc., Richland, Washington.

HNF-PRO-456, Water Quality, 1998, Fluor Daniel Hanford, Inc., Richland, Washington.

HNF-PRO-457, 1998, Environmental Requirements Evaluation, Fluor Daniel Hanford, Inc., Richland, Washington.

HNF-PRO-2364, Radioactive Airborne Effluent Sampling, 1998, Fluor Daniel Hanford, Inc., Richland, Washington.

HNF-SP-0098-10, Routine Environmental Monitoring Schedule, 1998, Fluor Daniel Hanford, Inc., Richland, Washington.

WAC 173-200, 1990, "Water Quality Standards for Ground Waters of the State of Washington, Washington Administration Code, as amended.

WAC 173-216, 1994, "State Waste Discharge Permit Program," Washington Administrative Code, as amended.

WAC 173-220, 1988, "National Pollutant Discharge Elimination System Permit Program," Washington Administrative Code, as amended.

WAC 173-303, 1991, "Dangerous Waste Regulations," Washington Administrative Code, as amended.

WAC 173-400, 1991, "General Regulations for Air Pollution Sources," Washington Administrative Code, as amended.

WAC 173-401, 1994, "Air Operating Permit Program," Washington Administrative Code, as amended.

WAC 173-460, 1991, "Controls for New Sources of Toxic air Pollutants," Washington Administrative Code, as amended.

WAC 173-480, 1991, "Washington State Ambient Air Quality Standards and Emission Limits for Radionuclides," Washington Administrative Code, as amended.

WAC 173-480, 1990, "Ambient Air Quality Standards and Emission Limits for Radionuclides," Washington Administrative Code, as amended. 
WAC 246-247, 1994, "Radiation Protection-Air Emissions," Washington Administrative Code, as amended.

Washington Clean Air Act of 1967, RCW 70.94, as amended.

WHC-EP-0491, Management Plan for Facility Efiluent monitoring Plan Activities, 1991, current revision, Westinghouse Hanford Company, Richland, Washington.

WHC-EP-0438-1, A Guide for Preparing Hanford Site Facility Effluent Monitoring Plans 1992, current revision, Westinghouse Hanford Company, Richland, Washington.

WHC-SA-1554-FP, Automated Bar Coding of Air Samples at Hanford, 1992, current revision, Westinghouse Hanford Company, Richland, Washington.

WHC-EP-0446-02, Quality Assurance Project Plan for Facility Effluent Monitoring Plan Activities, 1994, current revision, Westinghouse Hanford Company, Richland, Washington.

WHC-SD-CP-QAPP-017 Rev. 1B, Waste Sampling and Characterization Facility Quality Assurance Program Plan, 1995, Westinghouse Hanford Company, Richland, Washington. 